2015-05-25

Towards an alternative testing strategy for nanomaterials used in nanomedicine: Lessons from NanoTEST

\author{
Dusinska, M
}

http://hdl.handle.net/10026.1/4942

10.3109/17435390.2014.991431

Nanotoxicology

Informa UK Limited

All content in PEARL is protected by copyright law. Author manuscripts are made available in accordance with publisher policies. Please cite only the published version using the details provided on the item record or document. In the absence of an open licence (e.g. Creative Commons), permissions for further reuse of content should be sought from the publisher or author. 


\section{Nanotoxicology Nanotoxicology}

\section{Towards an alternative testing strategy for nanomaterials used in nanomedicine: Lessons from NanoTEST}

M. Dusinska, S. Boland, M. Saunders, L. Juillerat-Jeanneret, L. Tran, G. Pojana, A. Marcomini, K. Volkovova, J. Tulinska, L. E. Knudsen, L. Gombau, M. Whelan, A. R. Collins, F. Marano, C. Housiadas, D. Bilanicova, B. Halamoda Kenzaoui, S. Correia Carreira, Z. Magdolenova, L. M. Fjellsbø, A. Huk, R. Handy, L. Walker, M. Barancokova, A. Bartonova, E. Burello, J. Castell, H. Cowie, M. Drlickova, R. Guadagnini, G. Harris, M. Harju, E. S. Heimstad, M. Hurbankova, A. Kazimirova, Z. Kovacikova, M. Kuricova, A. Liskova, A. Milcamps, E. Neubauerova, T. Palosaari, P. Papazafiri, M. Pilou, M. S. Poulsen, B. Ross, E. Runden-Pran, K. Sebekova, M. Staruchova, D. Vallotto \& A. Worth

To cite this article: M. Dusinska, S. Boland, M. Saunders, L. Juillerat-Jeanneret, L. Tran, G. Pojana, A. Marcomini, K. Volkovova, J. Tulinska, L. E. Knudsen, L. Gombau, M. Whelan, A. R. Collins, F. Marano, C. Housiadas, D. Bilanicova, B. Halamoda Kenzaoui, S. Correia Carreira, Z. Magdolenova, L. M. Fjellsbø, A. Huk, R. Handy, L. Walker, M. Barancokova, A. Bartonova, E. Burello, J. Castell, H. Cowie, M. Drlickova, R. Guadagnini, G. Harris, M. Harju, E. S. Heimstad, M. Hurbankova, A. Kazimirova, Z. Kovacikova, M. Kuricova, A. Liskova, A. Milcamps, E. Neubauerova, T. Palosaari, P. Papazafiri, M. Pilou, M. S. Poulsen, B. Ross, E. Runden-Pran, K. Sebekova, M. Staruchova, D. Vallotto \& A. Worth (2015) Towards an alternative testing strategy for nanomaterials used in nanomedicine: Lessons from NanoTEST, Nanotoxicology, 9:sup1, 118-132, DOI: $10.3109 / 17435390.2014 .991431$

To link to this article: http://dx.doi.org/10.3109/17435390.2014.991431

Published online: 29 Apr 2015.

Submit your article to this journal $\sqsubset \pi$

Article views: 258

View related articles

View Crossmarkdither fins \& Conditions of access and use can be found at http://www.tandfonline.com/action/journallnformation?journalCode=inan20 


\title{
Towards an alternative testing strategy for nanomaterials used in nanomedicine: Lessons from NanoTEST
}

\author{
M. Dusinska' ${ }^{1}$ S. Boland ${ }^{2}$, M. Saunders ${ }^{3}$, L. Juillerat-Jeanneret ${ }^{4}$, L. $\operatorname{Tran}^{5}$, G. Pojana ${ }^{6,7}$, A. Marcomini ${ }^{7}$, K. Volkovova $^{8}$, \\ J. Tulinska ${ }^{8}$, L. E. Knudsen 9 , L. Gombau ${ }^{10}$, M. Whelan ${ }^{11}$, A. R. Collins ${ }^{12}$, F. Marano ${ }^{2}$, C. Housiadas ${ }^{13}$, D. Bilanicova ${ }^{6,7}$, \\ B. Halamoda Kenzaoui ${ }^{4,11}$, S. Correia Carreira ${ }^{14}$, Z. Magdolenova ${ }^{1}$, L. M. Fjellsbø ${ }^{1}$, A. Huk ${ }^{1}$, R. Handy ${ }^{15}$, L. Walker ${ }^{16}$, \\ M. Barancokova ${ }^{8}$, A. Bartonova' ${ }^{1}$, E. Burello ${ }^{11,17}$, J. Castell ${ }^{10}$, H. Cowie $^{5}$, M. Drlickova ${ }^{8,18}$, R. Guadagnini ${ }^{2}$, G. Harris $^{11^{\prime}}$,

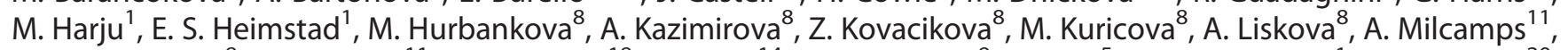 \\ E. Neubauerova ${ }^{8}$, T. Palosaari ${ }^{11}$, P. Papazafiri ${ }^{19}$, M. Pilou ${ }^{14}$, M. S. Poulsen ${ }^{9}$, B. Ross $^{5}$, E. Runden-Pran ${ }^{1}$, K. Sebekova $^{20}$, \\ M. Staruchova ${ }^{8}$, D. Vallotto ${ }^{6,7}$, and A. Worth ${ }^{11^{\prime}}$
}

\begin{abstract}
${ }^{1}$ Health Effects Laboratory-MILK, NILU - Norwegian Institute for Air Research, Kjeller, Norway, ${ }^{2}$ Unit of Functional and Adaptive Biology (BFA), Laboratory of Molecular and Cellular Responses to Xenobiotics (RMCX)), Univ Paris Diderot, Sorbonne Paris Cité, UMR 8251 CNRS, Paris, France, ${ }^{3}$ Department of Medical Physics \& Bioengineering, BIRCH, Bioengineering, Innovation \& Research Hub, St. Michael's Hospital, University Hospitals Bristol NHS Foundation Trust, Bristol, United Kingdom, ${ }^{4}$ University Institute of Pathology, Lausanne, Switzerland, Institute of Occupational Medicine, Riccarton, Edinburgh, UK, ${ }^{6}$ DFBC - Department of Philosophy and Cultural Heritage, University Ca' Foscari Venice, Venice, Italy, ${ }^{7} D A I S$ Department of Environmental Sciences, Informatics and statistics, University Ca' Foscari Venice, Venice, Italy, ${ }^{8}$ Faculty of Medicine, Slovak Medical University, Bratislava, Slovakia, ${ }^{9}$ Faculty of Health and Medicinal Sciences, Institute of Public Health, University of Copenhagen, Copenhagen, Denmark, ${ }^{10}$ Leitat Technological Center, Scientific Park, Barcelona, Spain, ${ }^{11}$ Institute for Health and Consumer Protection, European Commission Joint Research Centre, Ispra (VA), Italy, ${ }^{12}$ Department of Nutrition, University of Oslo, Oslo, Norway, ${ }^{13}$ Thermal Hydraulics and Multiphase Flows Laboratory, Institute of Nuclear \& Radiological Sciences \& Technology, Energy \& Safety, NCSR "Demokritos", Agia Paraskevi, Greece, ${ }^{14}$ Bristol Centre for Functional Nanomaterials, University of Bristol, Bristol, UK, ${ }^{15}$ School of Biomedical and Biological Sciences, Plymouth University, Plymouth, UK, ${ }^{16}$ Bristol Heart Institute, School of Clinical Sciences, University of Bristol, Bristol, UK, ${ }^{17}$ Computational Chemistry Group, RAPID Department (Risk Analysis of Products in Development), TNO, Zeist, The Netherlands, ${ }^{18}$ Centre for Chemical Substances and Preparations, Bratislava, Slovakia, ${ }^{19}$ Department of Biology, University of Athens, University Campus, Athens, Greece, and ${ }^{20}$ Medical Faculty, Institute of Molecular Biomedicine, Comenius University, Bratislava, Slovakia
\end{abstract}

\section{Abstract}

In spite of recent advances in describing the health outcomes of exposure to nanoparticles (NPs), it still remains unclear how exactly NPs interact with their cellular targets. Size, surface, mass, geometry, and composition may all play a beneficial role as well as causing toxicity. Concerns of scientists, politicians and the public about potential health hazards associated with NPs need to be answered. With the variety of exposure routes available, there is potential for NPs to reach every organ in the body but we know little about the impact this might have. The main objective of the FP7 NanoTEST project (www.nanotest-fp7.eu) was a better understanding of mechanisms of interactions of NPs employed in nanomedicine with cells, tissues and organs and to address critical issues relating to toxicity testing especially with respect to alternatives to tests on animals. Here we describe an approach towards alternative testing strategies for hazard and risk assessment of nanomaterials, highlighting the adaptation of standard methods demanded by the special physicochemical features of nanomaterials and bioavailability studies. The work has assessed a broad range of toxicity tests, cell models and NP types and concentrations taking into account the inherent impact of NP properties and the effects of changes in experimental conditions using well-characterized NPs. The results of the studies have been used to generate recommendations for a suitable and robust testing strategy which can be applied to new medical NPs as they are developed.

\footnotetext{
Abbreviations: AFM: atomic force microscopy; BBB: blood-brain barrier; BET: BrunauerEmmett-Teller; BSA: bovine serum albumin; CBMN: cytokinesis-block micronucleus; CS: calf serum; CNS: central nervous system; DCFH-DA: 2,7-dichlorodihydro-fluorescein diacetate; DLS: dynamic light scattering; DNA: deoxyribonucleic acid; ELISA: enzyme-linked immunosorbent assay; EDX/EDS: energy-dispersive X-ray spectroscopy; $\mathrm{FBS}$ : fetal bovine serum; $\mathrm{Fl}-25 \mathrm{SiO}_{2}$ : fluorescent $25 \mathrm{~nm}$ silica; GM-CSF: granulocyte macrophage colony-stimulating factor; $\mathrm{H}_{2} \mathrm{AX}$ : $\mathrm{H} 2 \mathrm{~A}$ histone family member X; HE: hydroethidine; HTS: high-throughput screening; IL:
}

\section{Keywords}

Hazard assessment, in vitro, nanoparticles, NanoTEST, testing strategy

\section{History}

Received 14 August 2014

Revised 2 November 2014

Accepted 19 November 2014

Published online 29 April 2015 
interleukin; LDH: lactate dehydrogenase; LTT: lymphocyte transformation test; $\mathrm{mBBr}$ : monobromobimane; MTT: 3-(4,5-dimethyl-thiazol-2-yl)-2,5-diphenyl-tetrazolium bromide; $\mathrm{NaFlu}$ : sodium fluorescein; NP: nanoparticle; NTA: nanoparticle tracking analysis; $\mathrm{OC}_{-}-\mathrm{Fe}_{3} \mathrm{O}_{4}$ : Na-oleate-coated iron oxide; PBMC: peripheral blood mononuclear cells; PBPK: physiologically based pharmacokinetic; PI: propidium iodide; PLGA-PEO: polylactic-co-glycolic acid-Poly poly ethylene oxide; (Q)SAR: quantitative structure-activity relationship; ROS: reactive oxygen species; RTqPCR: quantitative real time RT-PCR; SANS: small angle neutron scattering; SB: strand breaks; SD: stock dispersion; SEM: scanning electron microscopy; SLS: static light scattering; SOPs: standard operating procedures; SP-ICP-MS: single particle inductively coupled plasmamass spectrometry; TEM: transmission electron microscopy; $\mathrm{U}-\mathrm{Fe}_{3} \mathrm{O}_{4}$ : uncoated iron oxide; WST1: 2-(4 -iodophenyl)-3-(4-nitrophenyl)-5-(2,4-disulphophenyl)-2H-tetrazolium;

\section{Introduction}

The rapid and enormous development of nanotechnology has been accompanied by a deep concern about the effects that nanoparticles (NPs) may have on human health and the environment. However, the knowledge gaps in our understanding of the behaviour of NPs, their transformation and fate in different environments including biological systems, make it difficult to evaluate their toxic effects and to perform adequate hazard and risk assessment. Selection of the best endpoints and methods in appropriate cell models and adaptation, standardization and validation of methods are still needed.

NPs can potentially enter the human body through a range of exposure routes (Elsaesser \& Howard 2012; Hagens et al., 2007) including intravenous injection, inhalation and ingestion via the digestive tract. They can then translocate to the blood from where they can reach most organs and possibly accumulate, before being eliminated through processes that are not yet clearly understood (Oberdörster et al., 2005).

In the respiratory tract, NPs interact with bronchial and alveolar epithelial cells, inducing cell activation and reaction. Very small NPs may translocate through the lung epithelium and the endothelium of the blood vessels into the blood and lymph circulation. Similar mechanical properties as in the respiratory tract can be expected in the digestive tract cells in which NPs can induce cell activation and tissue reaction, oxidative stress and loss of the barrier functions of the epithelium. In the blood, NPs can interact with circulating cells, inducing cell activation, increased adhesion of the NPs to each other or endothelial cells. Interaction with cells of the vascular wall can induce vascular reaction, activation and vascular leakage, and uptake of NPs by endothelial cells and perivascular cells. The liver is the major site for biotransformation and defence against foreign materials and xenobiotics, and this is very likely also true for NPs, possibly inducing hepatocyte and/or sinusoidal endothelial and Kupffer cell activation. The kidney transports and excretes NPs from the blood to the urine, or reabsorbs them from urine. The central nervous system (CNS) is separated from the blood by the bloodbrain barrier (BBB), represented by a very specialized vascular system consisting of endothelial cells, pericytes and astrocytes, but limiting access to the brain. NPs may induce the activation of brain endothelial, astroglial and microglial cells. The placenta is a biological barrier of particular interest in relation to the sensitive nature of the foetus and NPs may induce placental inflammation associated with foetal defects. Representative cells and cell lines originating from these organs were used to test NPs selected in the NanoTEST project (Tables 1 and 2) and to select the best in vitro models to determine modes of action for hazard assessment (Juillerat-Jeanneret et al., 2015).

A strategy for in vitro toxicity testing in a regulatory context requires a battery of tests addressing different mechanisms and covering all main important toxicity endpoints. Thus, to identify relevant short-term hazard models, we used several standard toxicity assays for different markers such as cell viability, proinflammatory response, oxidative stress, genotoxicity, immunotoxicity, cell uptake and transport. OECD recommended methods were chosen where possible, such as in the case of genotoxicity (Magdolenova et al., 2012a,b) and when necessary methods were adapted for NP testing (Guadagnini et al., 2015a) and fully documented in relevant publications or NanoTEST protocols (www.nanotest-fp7.eu). The specific focus of our biomarker validation strategy was to identify the most suitable conditions for detecting a significant response and, by including relevant positive and negative controls, to ensure that the method is reliable and gives reproducible results.

Table 1. Selected nanoparticles (NPs).

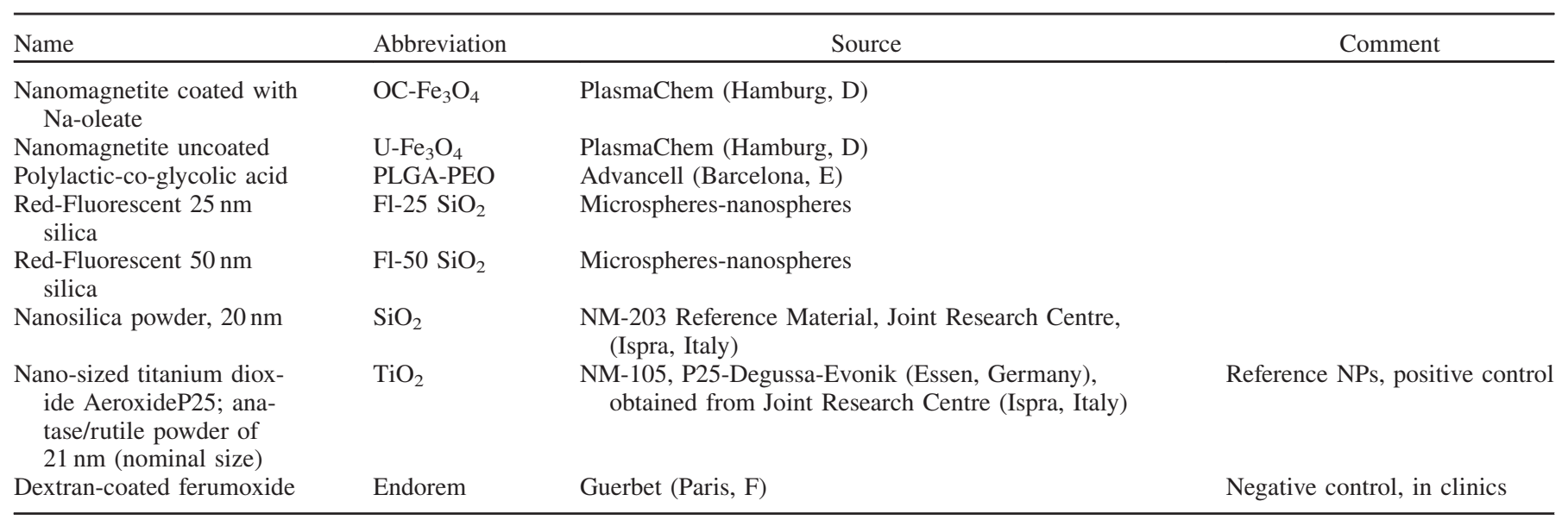


To verify the suitability of in vitro models, in vivo studies were carried out. A single i.v. administration of $\mathrm{TiO}_{2}$ or Na-oleate-coated iron oxide $\left(\mathrm{OC}-\mathrm{Fe}_{3} \mathrm{O}_{4}\right)$ NPs $(0.1,1$ and $10 \%$ of $\mathrm{LD}_{50}$ ) to young female rats did not elicit overt acute or subacute toxicity (Sebekova et al., 2014; Volkovova et al., 2015) but seemed to have an immunomodulatory effect. The in vitro model of human peripheral blood cells generally reflected in vivo responses of peripheral blood immune cells to $\mathrm{TiO}_{2}$ and OC$\mathrm{Fe}_{3} \mathrm{O}_{4}$ NPs in exposed rats and proved the reliability of our panel of immune assays proposed as biomarkers for assessment of immunotoxicity in vitro (Tulinska et al. in preparation). There was also a good correlation in genotoxicity tests between in vitro/ in vivo micronucleus tests and the comet assay for both $\mathrm{TiO}_{2}$ and OC- $\mathrm{Fe}_{3} \mathrm{O}_{4}$ NPs (Kazimirova et al., in preparation). In addition, in silico methods were considered and a new model for predicting the oxidative stress potential of oxide NPs was proposed (Burello $\&$ Worth, 2011, 2015). The in vitro and in silico methods developed for NPs used in nanomedicine can also be utilised for the assessment of health effects of NPs used and applied in other areas and thus can have a wider impact on all 3 R's (replacement, reduction and refinement of animals) for toxicity testing.

The overall aim of NanoTEST was to provide testing strategies for hazard identification and risk assessment of NPs, and to propose recommendations for evaluating potential risks associated with new medical NPs. The specific objective was to develop a set of master standard operating procedures (SOPs) for at least two assays for each type of toxicity (including cell viability, pro-inflammatory response, oxidative stress, genotoxicity, immunotoxicity, cell uptake and transport). The most advanced and standardised techniques would be adapted for automation and prepared for validation.

The project addressed the factors responsible for variability in the results of nanotoxicity studies - namely, the source and type of NP, method of preparation or synthesis, stabilizers used, dispersion method, state of agglomeration, presence of impurities; as well as variations in experimental conditions such as $\mathrm{pH}$, temperature and sonication. The treatment regime is critical; results can depend on cell type used, exposure time, dose, the assay method used, and possible interference with the detection system (Dusinska et al., 2011, 2012, 2013; Guadagnini et al., 2015a, 2015b) as discussed below. The overall goal of the current paper is to summarise the artefacts and issues identified in nanotoxicology, into a coherent set of tables and guidelines for use by the research community in the design of testing strategies and to suggest modifications of assays where appropriate.

\section{Characterization of NPs}

A recommended list of physico-chemical properties to be characterized when testing specific manufactured nanomaterials for human health and environmental safety, has been proposed by the OECD (Report no. 36ENV/JM/MONO(2012)40, 2012). It includes particle size distribution (in solid and in liquid media), shape, agglomeration/aggregation, water solubility/dispersability, as well as parameters occasionally measured such as octanolwater partition coefficient (where relevant), redox potential and radical formation potential. It is now clear that discrepancies between reported toxicity results are caused not only partly by different intrinsic properties, both physical (size, shape, etc.) and chemical (crystal structure, surface chemistry, etc.) of nominally similar, or identical, NPs, but also by the application of different testing conditions of NPs in physiological media, which could affect transport kinetics in the investigated fluids (Kato et al., 2009; Magdolenova et al., 2012a). Clearly, a testing strategy for nanomaterials needs to include a comprehensive characterization (Bouwmeester et al., 2011), including in particular a determination of the main physical and chemical properties of NPs, and the properties pertaining to NP behaviour in biological media used for evaluating toxicological effects. The most frequently employed techniques are scanning and transmission electron microscopy (SEM and TEM, respectively), Brunauer-Emmett-Teller (BET), dynamic or static light scattering (DLS and SLS, respectively), NP tracking analysis (NTA) and small angle neutron scattering (SANS; Hassellöv \& Kaegi, 2009). No single technique could adequately characterize a selected NP (Warheit, 2008); only a proper combination of various techniques is able to describe the

Table 2. Cell models selected for use in toxicity studies.

\begin{tabular}{|c|c|c|c|c|}
\hline Organ/tissue & Cell model & Abbreviation & References & Source \\
\hline \multirow{2}{*}{$\begin{array}{l}\text { Endothelial } \\
\text { cells }\end{array}$} & Rat brain-derived endothelial cells & EC219 & Juillerat-Jeanneret et al. (1992) & \\
\hline & Murine lung-derived endothelial cells & ECp23 & Juillerat-Jeanneret et al. (1992) & \\
\hline Liver & Rat liver macrophages (Kupffer cells) & & Aranda et al. (2013) & Primary culture \\
\hline \multirow[t]{2}{*}{ Lung } & Human lung-derived alveolar cells & A549 & Guadagnini et al. (2015a) & ATCC CCL-185 \\
\hline & Human lung-derived bronchial cells & 16HBE140 & $\begin{array}{l}\text { Guadagnini et al. (2015b); } \\
\text { Hussain et al. (2010) }\end{array}$ & \\
\hline Placenta & Placental choriocarcinoma cells & BeWo b30 & $\begin{array}{l}\text { Saunders (2009), Correia Carreira } \\
\text { et al., (2015), Poulsen et al. (2015); } \\
\text { Cartwright et al. (2011) }\end{array}$ & \\
\hline \multirow[t]{4}{*}{ Kidney } & Distal tubule epithelial cells & MDCK & Halamoda Kenzaoui et al. (2013b) & ATCC CCL-34 \\
\hline & Proximal tubule epithelial cells & LLC-PK & Halamoda Kenzaoui et al. (2013b) & ATCC CL-101 \\
\hline & Monkey kidney cells & $\operatorname{COS} 1$ & Magdolenova et al. (2012a,b) & ATCC CRL-1573 \\
\hline & Human kidney cells & HEK 291 & Magdolenova et al. (in preparation) & \\
\hline
\end{tabular}


Table 3. Average hydrodynamic diameters of $\mathrm{TiO}_{2}$ NPs dispersed in stock dispersion SD-TB and SD-TC then added to investigated biological media $\left(\mathrm{TiO}_{2} \mathrm{NPs}\right.$ concentration in media: $\left.0.3 \mathrm{mg} / \mathrm{ml}\right)$ and measured by dynamic light scattering (DLS) after $30 \mathrm{~min}$ and $48 \mathrm{~h}$.

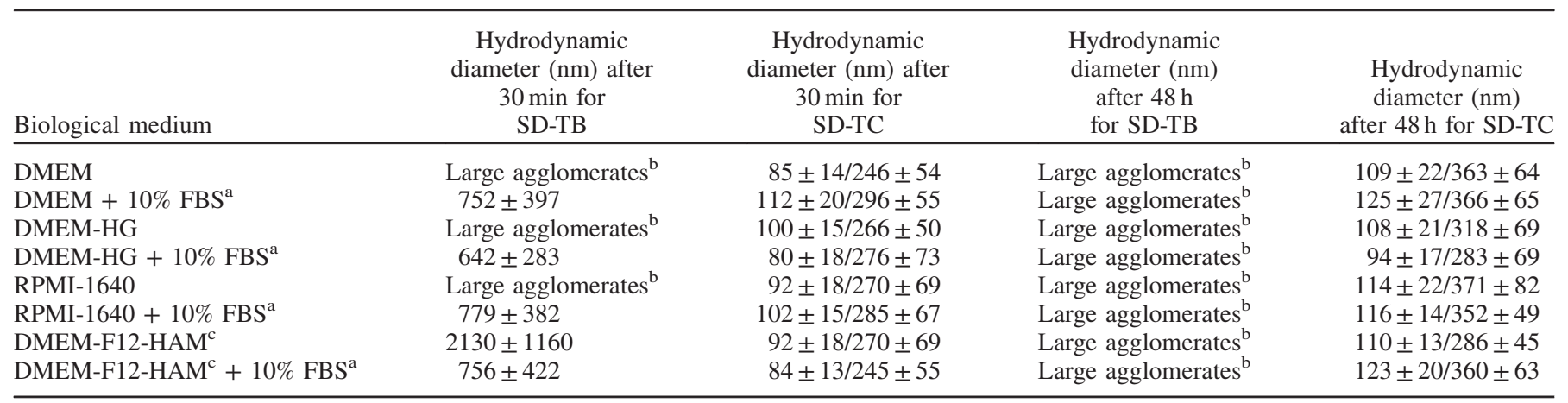

$\mathrm{TiO}_{2}$ NPs, an anatase/rutile powder of $21 \mathrm{~nm}$ (nominal size), NM-105. Sub-samples of NM-105 were packed under Good Laboratory Practice conditions and preserved under argon in the dark until use.

$\mathrm{TiO}_{2}$ NPs dispersion protocol SD-TB. Stock solutions of $\mathrm{TiO}_{2} \mathrm{NPs}$ were made by weighing $20 \mathrm{mg}$ of $\mathrm{TiO}_{2} \mathrm{NPs}$ and suspending in $10 \mathrm{ml}$ of culture medium containing $15 \mathrm{mM}$ Hepes buffer without FBS in a $15 \mathrm{ml}$ plastic tube. The suspensions were sonicated using an ultrasonic probe sonicator (Labsonic, Sartorius) for $3 \mathrm{~min}$ at $60 \mathrm{~W}$ (on ice and water mixture to allow the cooling down of the solution). Within 2 min after sonication and directly after $10 \mathrm{sec}$ of vortexing, the solution was divided into 10 microcentrifuge tubes and stored at $-20^{\circ} \mathrm{C}$ for further use. Immediately before use $\mathrm{TiO}_{2}$ NPs were thawed, vortexed for $10 \mathrm{~s}$ before being immediately sonicated for 1 min (on ice and water mixture) at $60 \mathrm{~W}$, and added to cell culture medium to achieve a $0.3 \mathrm{mg} / \mathrm{ml}$ working solution.

$\mathrm{TiO}_{2}$ NPs dispersion protocol SD-TC. Stock solutions at $5 \mathrm{mg} / \mathrm{ml}$ of $\mathrm{TiO}_{2} \mathrm{NPs}$ were prepared fresh each time. To prepare $1 \mathrm{ml}$ of stock solution, $1 \mathrm{ml}$ of

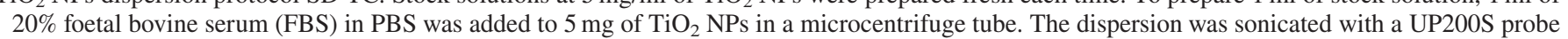
sonicator by Hielscher Ultrasonic Technology (Teltow, Germany) for 15 min at 100 Watt (cycle: 100\%). The dispersion was cooled during sonication with an ice/water bath in order to prevent heating of the dispersion. The resulting stock suspension was added to cell culture medium to achieve a $0.3 \mathrm{mg} / \mathrm{ml}$ working suspension.

All media were purchased from Sigma-Aldrich RPMI - 1640 cat.no. R8758; DMEM cat.no.D6046; DMEM-HG cat.no. D5796; DMEM-F12-HAM cat.no. D6421

${ }^{\mathrm{a}}$ For ethical reasons, only one type of FBS was used: Sigma-Aldrich cat.no.F9665.

${ }^{\mathrm{b}}$ Formation of very large agglomerates not detectable by DLS technique, unstable dispersion.

${ }^{c}$ DMEM-F12-HAM was supplements with $1 \%$ Amphotericin B (cat. no. A2942) + 1\% L-Glutamine-Penicillin-Streptomycin solution (cat. no. G6784).

NP properties driving the observed toxicological behaviour. There is no consensus yet on the strategy to identify an optimal set of techniques and procedures, mainly because of the rapidly increasing variety of available NPs and the limited comparative evaluations carried out so far on the advantages and constraints of each analytical method and technique applied to date in toxicological testing (Stone et al., 2010; Zuin et al., 2007).

\section{Preparation of NP dispersions for treatment of cells}

An accurate characterization of NPs additionally to primary characteristics at different stages of testing (i.e. as supplied, before/after administration, during the course of experiments) is essential to find a meaningful correlation between NP structural properties and toxicity (Jiang et al., 2009; Oberdörster et al., 2005; Powers et al., 2007). Properties of nanomaterials change depending on the surrounding environment. NPs tend to precipitate, agglomerate and aggregate, which can affect their toxic potential and the tendency for agglomeration/aggregation has already been proposed as a key property for the interpretation of (eco)toxicological results (Kato et al., 2009). The stability of the dispersion depends on the effect of various forces (electrostatic and steric hindrance, Van der Waals forces, magnetic attraction force), which are determined mainly by the properties of the particle and the dispersing medium (as mentioned above) and particle surface properties, i.e. surface chemistry (OECD Report no. 36ENV/JM/MONO(2012)40, 2012). Most proposed protocols so far are simply derived from protocols previously developed for standard chemicals, and rarely cope with the intrinsic instability of NPs in biological media (Handy et al., 2012). Differences in handling procedures and dispersion protocols for NPs have recently been demonstrated to strongly affect the overall toxicological behaviour of NPs (Magdolenova et al., 2012a). A satisfactory stability of dispersion in culture medium is, however, sometimes extremely difficult to achieve because of the intrinsic properties of some NPs and the selected experimental conditions (Handy et al., 2012; Ramirez-Garcia et al., 2011). Within NanoTEST, primary and secondary characteristics of NPs were published by Guadagnini et al. (2015a). Properties of NPs and their toxic effects can also be influenced by the different physical and chemical properties of solvents used for dispersing or dissolving them. Factors such as $\mathrm{pH}$, salinity, water hardness, temperature and the presence of dissolved or natural organic particles can influence the biological reactivity of NPs. Thus, they might behave differently in water, culture medium, PBS and other solvents (Handy et al., 2012), with pronounced effects on their uptake, cellular localization and hence the observed toxic response. For in vitro toxicity testing, it is essential to characterize NPs in the treatment medium immediately before and if possible also after treatment. Particle size, state of agglomeration, surface properties and stability of the dispersion stock solution as well as of the NPs dispersed in the final treatment medium should be measured. However, methods to follow the transformation and fate of NPs are not yet fully developed. It is recommended to measure particle size distribution using at least two methods [OECD Report no. 36ENV/JM/MONO(2012)40, 2012]. In NanoTEST, a wide range of techniques were employed including SEM, TEM, atomic force microscopy (AFM) and DLS. The experience from NanoTEST showed that the NP dispersion should always be freshly prepared, i.e. immediately before the experiment, as the stability of NP suspensions is in most cases limited (Table 3). Most common dispersion protocols include bovine serum albumin (BSA) or fetal bovine or calf serum (FBS or CS), as the presence of proteins prevents agglomeration. The data on stabilities of $\mathrm{TiO}_{2} \mathrm{NPs}$ in various culture media showed that the preparation of stock dispersion and use of serum proteins in stock dispersion as well as in final medium have impact on NP size and dispersion stability. While a stock dispersion prepared without 
serum resulted in large agglomerates, preparation with FBS gave a more stable (up to $48 \mathrm{~h}$ ) bimodal dispersion with two peaks more or less in the nanosized range (Table 3). However, the protein corona that forms around NPs affects their toxicological properties (Lundqvist et al., 2011; Mahon et al., 2012; Magdolenova et al., 2012a; Mortensen et al., 2013; Yang et al., 2013). Sonication of the dispersion also protects against agglomeration and is widely used. However, severe sonication can affect the properties of nanomaterials (Taurozzi et al., 2011).

It is also important to note that the in vitro treatment medium should mimic real in vivo conditions as closely as possible, e.g. addition of serum proteins is conceivable for endothelial or blood cells but not for respiratory cell cultures for which surfactant components could be used to achieve good dispersions; composition and proportion of proteins and other components should be similar to those present in the organism.

\section{Expression of concentrations (metrics)}

The concentration of NPs is commonly expressed in mass units $[\mu \mathrm{g} / \mathrm{ml}],\left[\mu \mathrm{g} / \mathrm{cm}^{2}\right]$ or $[\mu \mathrm{g} / \mathrm{cell}]$. The relationship between the mass units can vary depending on the type of culture plates, amount of medium and number of cells used. In addition, concentrations can be expressed as number of NPs per $\mathrm{ml}$, per $\mathrm{cm}^{2}$ or per cell as well as surface area of NPs per $\mathrm{ml}$, per $\mathrm{cm}^{2}$ or per cell. In the NanoTEST project, we recommended that concentrations be expressed in at least two different units, not only as mass but also as number of NPs or as surface area, since surface properties and size are among those physicochemical properties of NPs that may impact on toxicity and thus these units might be more informative for the comparative evaluation of toxicity of different NPs. Primary particle size and agglomerate size of the suspensions should thus be measured which will also allow calculation of the number concentration if this is not determined experimentally (calculation using nominal values should be avoided). The surface area should also be determined experimentally when possible as porosity and roughness will influence the actual surface area of the particles. The expression of concentration per cell seems most appropriate for NP testing and should be considered in in vitro toxicity testing. In the NanoTEST experiments, concentrations were expressed in $\mu \mathrm{g} / \mathrm{ml}$ and in $\mu \mathrm{g} / \mathrm{cm}^{2}$ and aspects of experimental set up such as the plate surface area, number of cells, volume of medium used, for all toxicity tests were the same whenever possible. In the future, concentration per cell could or should be verified using emerging methods such as single particle inductively coupled plasma-mass spectrometry analysis (SP-ICP-MS) or imaging with energy-dispersive X-ray spectroscopy (EDX/EDS) subject to particle composition (Laborda et al., 2013).

Concentrations used should be realistic, i.e. relevant to possible human exposures. For some assays, notably the comet assay, recommended concentrations should range from non-toxic to around $80 \%$ cell viability, since breakage of deoxyribonucleic acid (DNA) can be a secondary effect of cytotoxicity and so the use of cytotoxic concentrations could give false positive results. In some tests (micronucleus assay), the toxicity range is normally from non-toxic to around $50 \%$ viability.

NPs have a tendency to agglomerate and therefore the concentration of NPs should not exceed the level at which agglomeration is enhanced. The stability of the dispersion decreases with increasing concentration. When agglomeration occurs, it is difficult to quantify exposure as it varies and is most likely reduced either due to changes in concentration mass, reduced particle count or surface area. Agglomeration of NPs affects their bioavailability to the cell and thus might lead to false positive/negative results. High concentrations can also give rise to overload effects that can be misinterpreted as evidence of cytotoxicity (Wittmaack, 2011).

\section{Exposure conditions: time of treatment and concentration range}

The exposure time is crucial. For testing ordinary chemicals in vitro, 3-6 h and $24 \mathrm{~h}$ exposures are usually recommended. NPs may need more time to enter the cells. NP uptake in cells with macrocytic activity is usually shorter than in most of the other cell types. Liver macrophages (Kupffer cells) but not hepatocytes were able to internalize silica NPs after $4 \mathrm{~h}$ (Aranda et al., 2013).

For NP toxicity studies in NanoTEST, both shorter $(1-3 \mathrm{~h})$ as well as longer (at least 24-72 h) treatments were used depending on the endpoint studied; a longer treatment was preferred to ensure uptake by cells.

For certain tests, such as the micronucleus assay, $24 \mathrm{~h}$ treatment is necessary to cover at least $1-1.5$ cell cycles, as some compounds including NPs might be active only at a specific cell cycle stage and also access to nuclear DNA will be facilitated by the absence of nuclear membrane during mitosis. The concentration range of nanomaterials should ensure adequate exposure that reflects possible exposure scenarios and the concentrations used need to be scientifically justified.

\section{Positive and negative controls and reference standards}

Positive and negative controls are integral parts of the testing procedure that are always included in experiments, for the purpose of quality control, to demonstrate correct performance of the assay and to ensure reproducibility. Negative controls consist of dispersion solutions without NPs but otherwise processed identically to NP dispersions (e.g. same sonication schedule, etc.). A positive control (an agent inducing toxicity appropriate to the particular assay and cell type) is included in each experiment to check that the assay is performing correctly and giving the expected positive response. In the case of metal NPs, metal ions should be used as an additional control, since metal ions released from NPs can cause production of reactive oxygen species (ROS) via Fenton-like reactions and so it is important to test whether the presence of these ions, rather than the NPs, is inducing toxicity.

Coating materials or NP stabilizers can also cause toxicity and thus should also be tested and included in the experimental set-up as additional reference material (control). NPs are good carriers, and if a stabilizer or coating is toxic, low, normally non-toxic concentrations can cause damage due to their enhanced internalization into cells. Within NanoTEST, OC- $\mathrm{Fe}_{3} \mathrm{O}_{4} \mathrm{NPs}$ were tested and Na-oleate was included in the genotoxicity testing as well as other tests of cell stress (Magdolenova et al., 2015; Schütz et al., 2014). These additional controls to discriminate between coating/solvent/stabiliser effects and effects of NPs are of utmost importance.

A challenge for nanotoxicity studies is the choice of nanospecific positive/negative controls. In the NanoTEST project, dextran-coated iron oxide Endorem ${ }^{\circledR}$ was used as negative control (Cowie et al., 2015). There are several initiatives currently focusing on selection of nanomaterials with appropriate properties to be recommended as reference standards (Stone et al., 2010; reviewed by Stefaniak et al., 2013). ZnO NPs were suggested as a positive control for the comet assay in the EU NanoGenotox project report (http://www.nanogenotox.eu/files/PDF/nanogenotox_web.pdf); however, results were not reproducible, being particularly affected by the type of cell used. Certified nanospecific reference standards for use as positive controls are urgently needed. The NanoTEST project also suggested several positive controls for each toxicity endpoint as discussed below. Reproducibility is crucial for any test method but especially for 
NPs with so many factors that may contribute to variability between and within tests. Thus, building historical positive and negative controls (average values from all experiments performed in the laboratory with particular cell model and test over period of several years) as used in regulatory toxicology is good practice for quality assurance and evaluation of safety of nanomaterials.

\section{Bioavailability of nanomaterial: uptake, subcellular localization and NP release}

For evaluation of toxicity generally, knowledge of bioavailability of the tested compound is essential. In the case of NPs, uptake studies are needed to show whether NPs are able to reach and enter the cells. The internalization of NPs is highly sizedependent; however, uptake might not follow commonly defined size limits, and kinetics of uptake for the same type of NPs varies in the different cell types (dos Santos et al., 2011). NP transport is most affected by tightness of the cell barrier, with transport increasing in the order: brain $<$ placenta $<$ kidney after $2 \mathrm{~h}$ and brain $<$ kidney $<$ placenta after $24 \mathrm{~h}$ exposure as shown from transport studies of $\mathrm{OC}-\mathrm{Fe}_{3} \mathrm{O}_{4}$ NPs utilising different cell types (Figure 1; Correia Carreira et al., 2015; Halamoda Kenzaoui et al., 2012a, 2013b). The different order in extent of transport with time is likely to be due to changes in cell growth in each model and will reflect differences in the tightness of the barrier formed.

Uptake and subcellular localization of NanoTEST NPs were extensively studied in different cell types (Correia Carreira et al., 2015; Halamoda Kenzaoui et al., 2012a,b,c, 2013a,b; Magdolenova et al., 2015; Poulsen et al., 2015). If toxicity testing gives negative results, toxic effects cannot be excluded unless uptake of NPs has been demonstrated. On the other hand, a demonstration of non-uptake does not necessarily imply nontoxicity, since NPs may act indirectly via oxidative stress (Hussain et al., 2010) or inflammation, in which case they do not need to be internalized.

Studies of transport and release of NPs are limited to labelled NPs and NPs that can be detected at low concentration in buffers and to NPs which do not agglomerate under such cell culture conditions. They are also limited due to lack of analytical methods

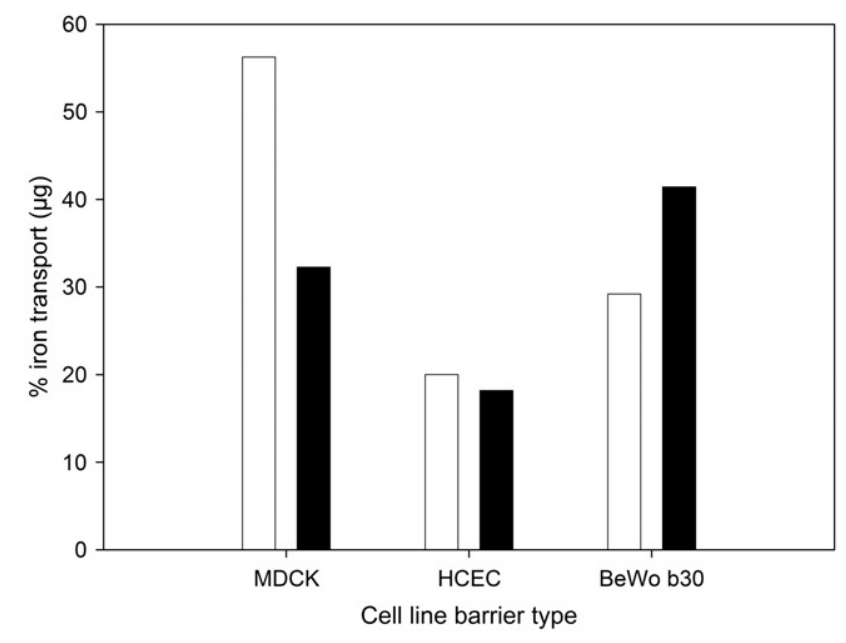

Figure 1. Cell line and exposure-dependent transport of $\mathrm{OC}-\mathrm{Fe}_{3} \mathrm{O}_{4} \mathrm{NPs}$ across cell barriers. The appearance of $\mathrm{OC}-\mathrm{Fe}_{3} \mathrm{O}_{4}$ NPs in the basal chamber was determined over the course of $2 \mathrm{~h}$ (open bars) and $24 \mathrm{~h}$ (filled bars). The initial applied amount of iron of $50 \mu \mathrm{g}$ was added to the apical chamber $(100 \mu \mathrm{g} / \mathrm{mL})$ and results are expressed as the percentage of the iron added to the apical chamber as detected in the basal chamber, quantified using the Prussian blue reaction and normalised to the amount transported across the Transwell insert ( $3 \mu \mathrm{m}$ Costar polyester membrane) in the absence of cells. and by the physical properties of the membranes used to develop two-chamber models as Transwell ${ }^{\circledR}$ inserts. Permeable membranes are available from a number of manufacturers and can differ widely in terms of composition, coating and pore size, all of which have the potential to introduce artefacts in cell seeding and NP interactions (Ragnaill et al., 2011; Saunders, 2009).

\section{Selection of cell models and assays}

Appropriate cellular model systems were selected in the NanoTEST project, representing different target organs and retaining organ-specific functions including cell activation and metabolic modification.

Criteria for selection of the best cell models (either primary cells or cell lines) include (a) their commercial availability, (b) their growth in culture media with minimal addition of growth factors which could be absorbed by the NPs, (c) expression of organ specific functions and (d) their stability under culture conditions. The initial selection and evaluation of cells (under NanoTEST) resulted in the adoption of a range of cell models as laid out in Table 2.

NP-induced toxicity may primarily result from direct interaction of particles with cells and cell organelles such as mitochondria, or DNA, or indirectly through the enhanced production of ROS by cellular constituents in response to their interaction with the particles (Magdolenova et al., 2014). Both pathways may depend on surface properties, the presence of transition metals, intracellular iron mobilization and lipid peroxidation processes. ROS can also be the cause of the secondary toxicity, via the inflammatory response of host cells. Oxidative stress has often been described as a key mechanism underlying the ability of NPs to cause cellular injury including DNA damage (Karlsson, 2010).

The broad range of toxicity assays tested under NanoTEST, including cytotoxicity, oxidative stress, inflammatory stress, immunotoxicity, genotoxicity, uptake and transport assays, are described in more detail in (Aranda et al., 2013; Correia Carreira et al., 2015; Guadagnini et al., 2015a, 2015b; Halamoda Kenzaoui et al., 2012a,b,c, 2013a,b; Harris et al., 2015; Kazimirova et al., 2012; Magdolenova et al., 2012a,b, 2015; Poulsen et al., 2015; Tulinska et al., 2015). SOPs for each selected model and assay, detailed culture conditions, exposure to the NPs and experimental protocols are described in a database, available from the project website (www.nanotest-fp7.eu).

We have evaluated statistically the results of experiments comparing cells representing different organs. Cytotoxic effects induced by NPs depend on the test used, exposure conditions and the cell type (Aranda et al., 2013; Correia Carreira et al., 2015; Guadagnini et al., 2015; Halamoda Kenzaoui et al., 2012a,c, 2013a,b; Harris et al., 2015; Kazimirova et al., 2012; Magdolenova et al., 2012a, 2015; Poulsen et al., 2015; Tulinska et al., 2015). The data also suggest that while there are differences between the cell lines, the strongest effect is from the NPs as seen with the OC- $\mathrm{Fe}_{3} \mathrm{O}_{4} \mathrm{NPs}$ results (Figure 2). For genotoxicity screening of NPs, the various cell types used give consistent results but with different sensitivity, allowing the study of target organ specificity and cell type sensitivity (Cowie et al., 2015).

\section{Technical limitations of the assays: possible interference of nanomaterial with the test}

Properties of NPs such as adsorption capacity, optical properties, hydrophobicity, chemical composition, surface charge and surface properties, catalytic activities as well as agglomeration can result in interference with standard toxicity tests (Aranda et al., 2013; Guadagnini et al., 2015a; Kroll et al., 2012). The interference of 
NPs with specific assays was observed for metallic oxide solid core NPs and was demonstrated with a range of in vitro cell viability assays [MTT (3-(4,5-dimethyl-thiazol-2-yl)-2,5-diphenyl-tetrazolium bromide], LDH (lactate dehydrogenase), WST-1 (2-(4-iodophenyl)-3-(4-nitrophenyl)-5-(2,4-disulphophenyl)-2Htetrazolium), Annexin V/PI (propidium iodide), neutral red, caspase activation, propidium iodide, ${ }^{3} \mathrm{H}$-thymidine incorporation, automated cell counting], inflammatory responses (ELISA for granulocyte macrophage colony-stimulating factor (GM-CSF), interleukin (IL)-6 and IL-8] and oxidative stress detection [monoBromoBimane $(\mathrm{mBBr})$, dichlorodihydro-fluoresceindiacetate (DCFH-DA), NO assays; Guadagnini et al., 2015a; Kroll et al., 2012]. Interferences found were assay as well as NPspecific. Thus, the evaluation of possible interference is required to ensure reliable results. This is mainly relevant for cytotoxicity assays, oxidative stress responses of cells and the production by the cells of bio-molecules such as peptides, proteins or others (Guadagnini et al., 2015a). It is clear that for nanotoxicity testing most of the assays need to be adapted and modified to avoid measuring artefacts. Aranda et al. (2013) showed that despite the quenching effect of NPs on DCFH-DA assay, it can be considered as a useful tool for quantitative measurement of NPs-induced oxidative stress by minor modifications of the standardized protocol. Additional standards need to be included as controls for the interference. For genotoxicity, interference was reported so far with the micronucleus test (Gonzalez et al., 2011; Magdolenova et al., 2012b) and the comet assay (Karlsson, 2010; Stone et al., 2009). The protocol for the micronucleus assay needed modification as cytochalasin B (used in this assay) inhibits endocytosis and may prevent uptake of NPs (Gonzalez et al., 2011; Magdolenova et al., 2012b). Using the comet assay, with 6 NPs, we found no interference. (Magdolenova et al., 2012b). However, to prevent false-negative/false-positive results, we recommend testing for possible interference of NPs in the gel, using both untreated cells and cells exposed to a known genotoxic compound (causing DNA strand breaks as well as oxidized DNA lesions). This would be a sensible precaution to be sure that no overestimation or underestimation of damage is occurring.

\section{Testing strategy}

We investigated whether tests used in the NanoTEST are reliable, give reproducible results and are suitable for NP testing. In addition, we set out to validate a battery of tests covering all important toxic endpoints (Table 4). Methodological consideration of these tests has been addressed in Guadagnini et al. (2015a) for cytotoxicity, oxidative stress and inflammatory markers and for genotoxicity in Magdolenova et al. (2012b).

As mentioned above, one of the main obstacles for assessing the toxicity of nanomaterials is the lack of knowledge of how physicochemical properties relate to the interaction of NPs with biological systems and the mechanism of toxicity. It is clear that physical and chemical properties can influence NP behaviour and may have an impact on toxicity; they must therefore be an integral part of toxicity testing. This is one of the key aspects of toxicity screening strategies (Dusinska \& NanoTEST Consortium, 2009; Dusinska et al., 2011, 2012, 2013). Both primary and secondary characterizations of tested NPs are crucial, including in situ characterization during exposure. The physico-chemical properties that should be considered for assessing toxic effects of nanomaterials include as a minimum chemical composition, particle size, shape, surface properties, size distribution, agglomeration state and crystal structure. Regarding the likelihood of biomolecular corona formation, it is also important to set up experimental conditions that can mimic exposure in humans. As NPs change their properties depending on the surrounding milieu, we recommend at least two different exposure conditions for testing the NP's effects (Magdolenova et al., 2012a).

An important question is whether the commonly used assays for chemicals could be applied to NPs. Our results show that it is not always possible to use these assays without careful adaptation because of possible interference (Guadagnini et al., 2015a), especially between NPs, the dye and the optical detection or with the assay components during the experiment (Tables 4-6). It is therefore of crucial importance to test possible interference of all studied NPs with the foreseen methods prior to evaluating cellular responses to NPs. To avoid these interferences, special adaptations of standard toxicity tests are also proposed [refer Tables 4 and 5, and Guadagnini et al. (2015a) for more detailed description]. Furthermore, all the assays do not have the same sensitivity and it is important to choose the most sensitive appropriate assay. From our results, for the oxidative stress markers, the thiol depletion and induction of antioxidant enzymes seem to be more sensitive than the measure of ROS (Guadagnini et al., 2015b). Our proposal for further evaluation of testing strategies is to perform first a battery of assays for validation of the effects of a representative set of well-characterized NPs on the target cells; then if appropriate and available, to screen larger banks of
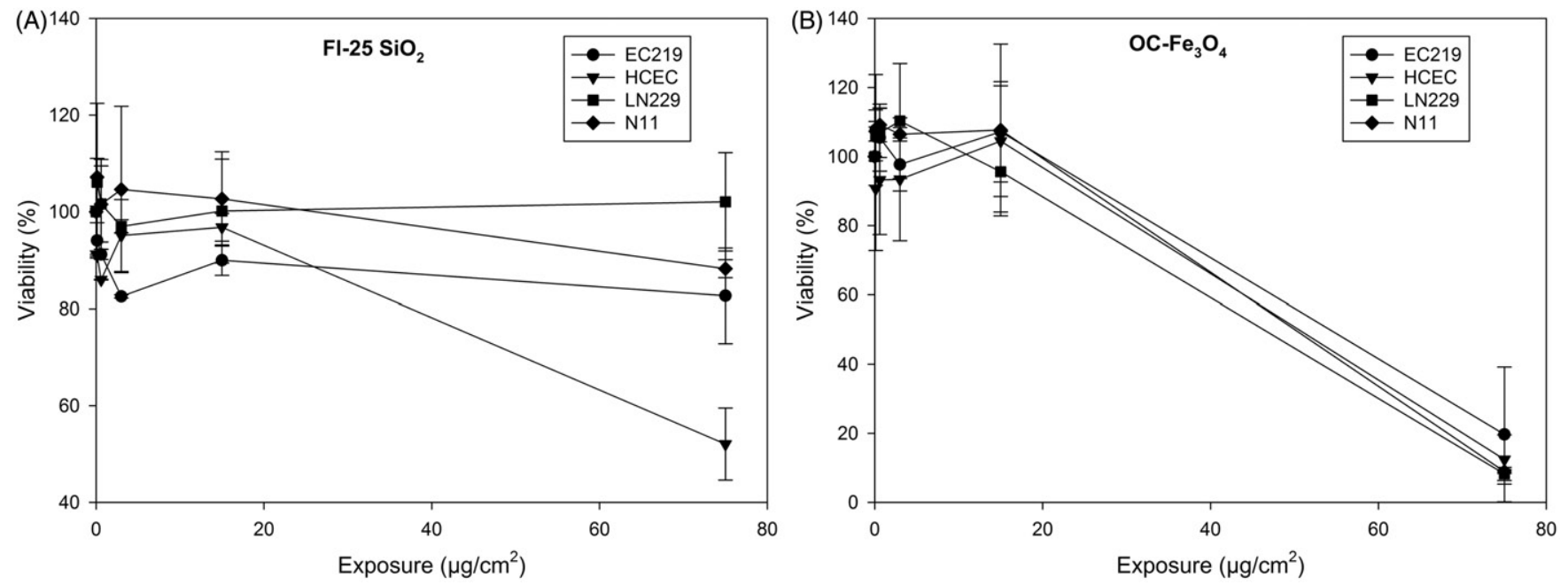

Figure 2. Cell viability of EC219, HCEC, LN229 or N11 cells exposed to (A) Si-25 or (B) OC-Fe $\mathrm{O}_{4}$ NPs for $72 \mathrm{~h}$ as measured by the MTT assay. Values represent average \% of untreated control \pm SD of three separate experiments for each exposure. 

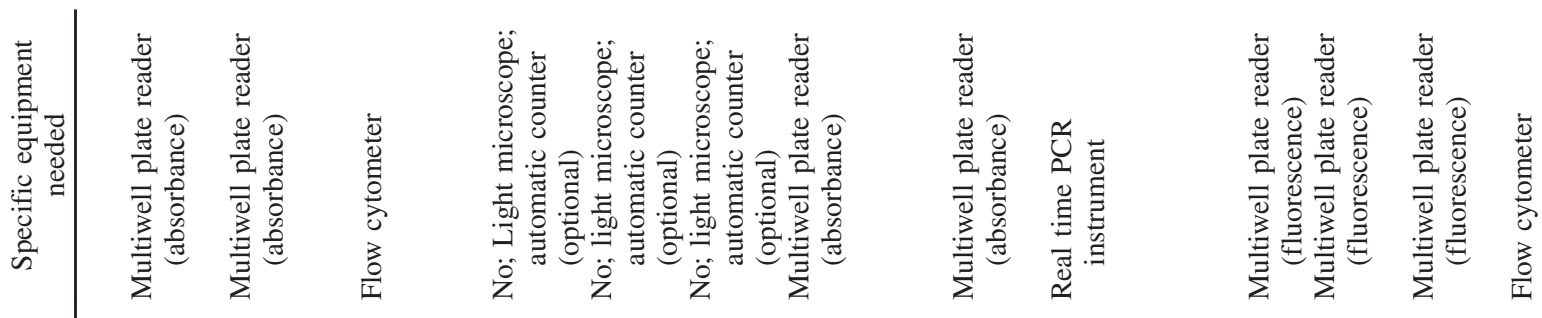

䋆

蚝:

$$
\stackrel{\infty}{\otimes}
$$

$$
\text { ż }
$$

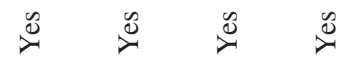

$\stackrel{0}{2}$

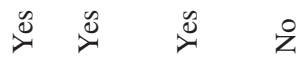

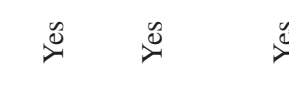

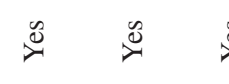

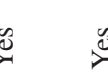

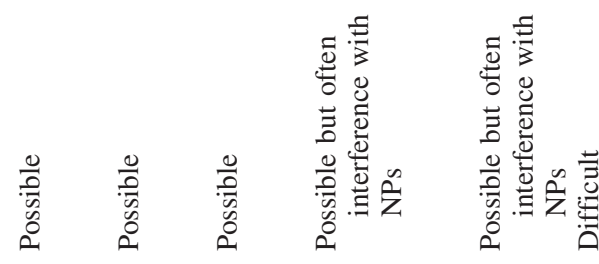

$\check{\varnothing}$

$\begin{array}{ll}\frac{0}{0} & \frac{0}{0} \\ 0 & \frac{\pi}{0} \\ 0 & 0 \\ 0 & 0\end{array}$

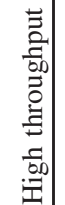

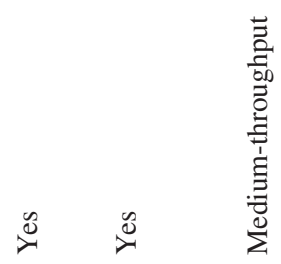

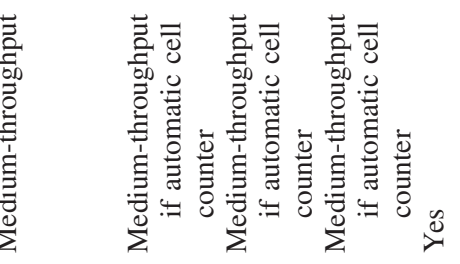

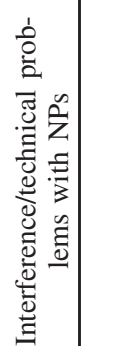
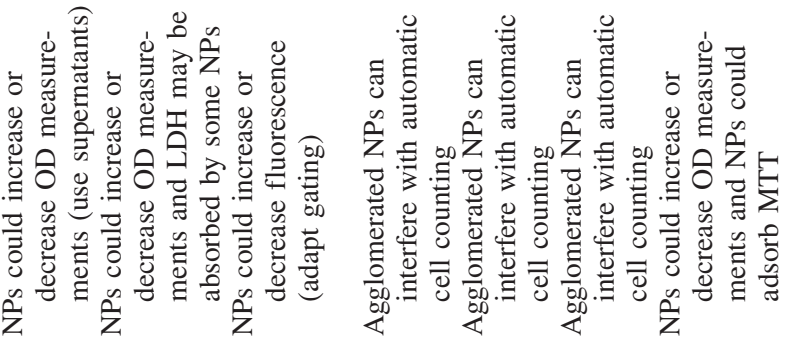

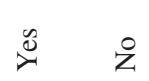

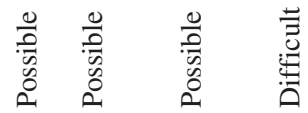

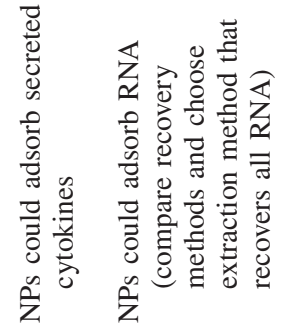

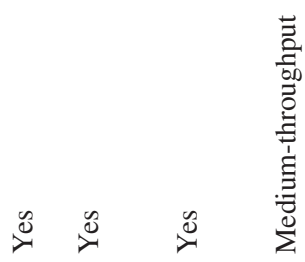

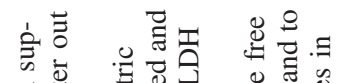

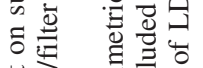

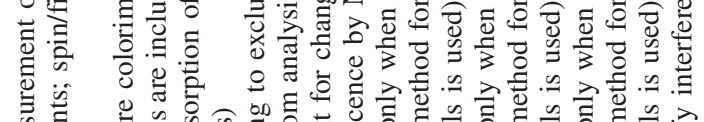

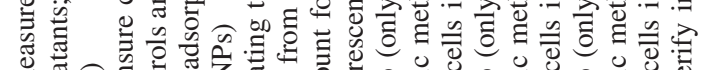

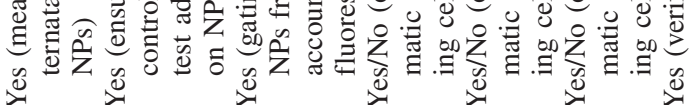

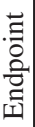

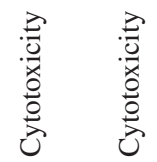

$\underbrace{\substack{0 \\ 0}}_{\substack{0 \\ 0}}$

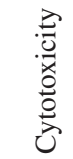

$\begin{array}{lll}\frac{2}{0} & \frac{2}{0} & \frac{2}{0} \\ .0 & 0 & 0 \\ 0 & 0 & 0 \\ 0 & 0 \\ 0 & 0 & 0\end{array}$

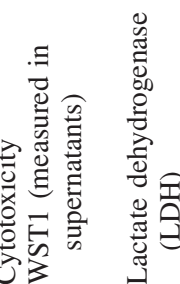

ב⿱⺈

忿
른

竞
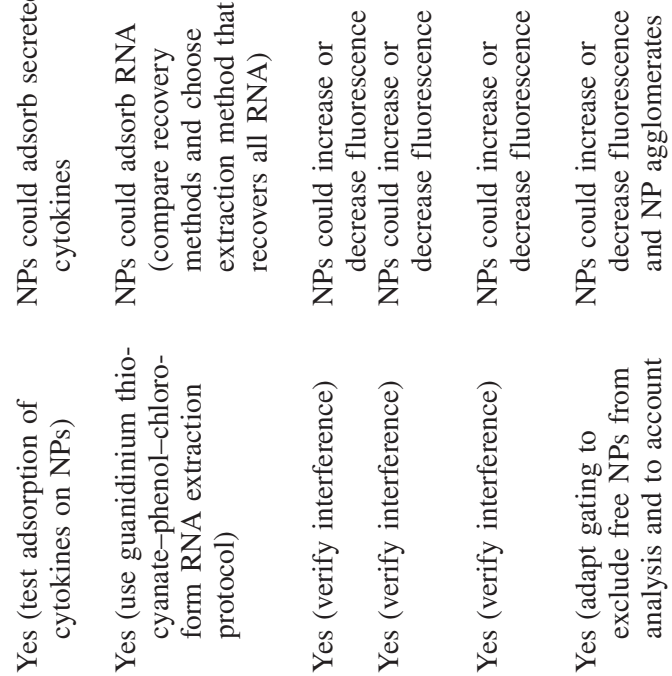

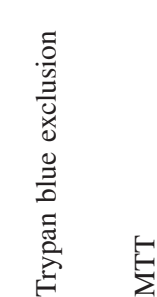

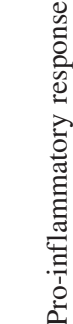

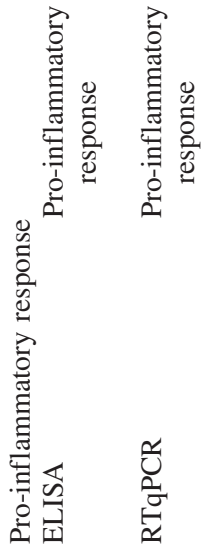

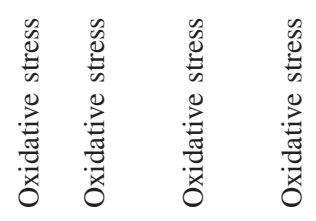

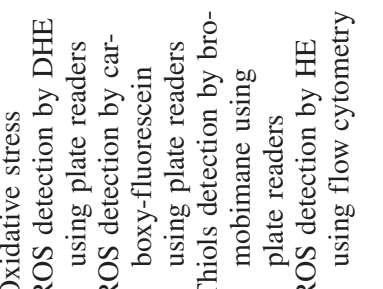




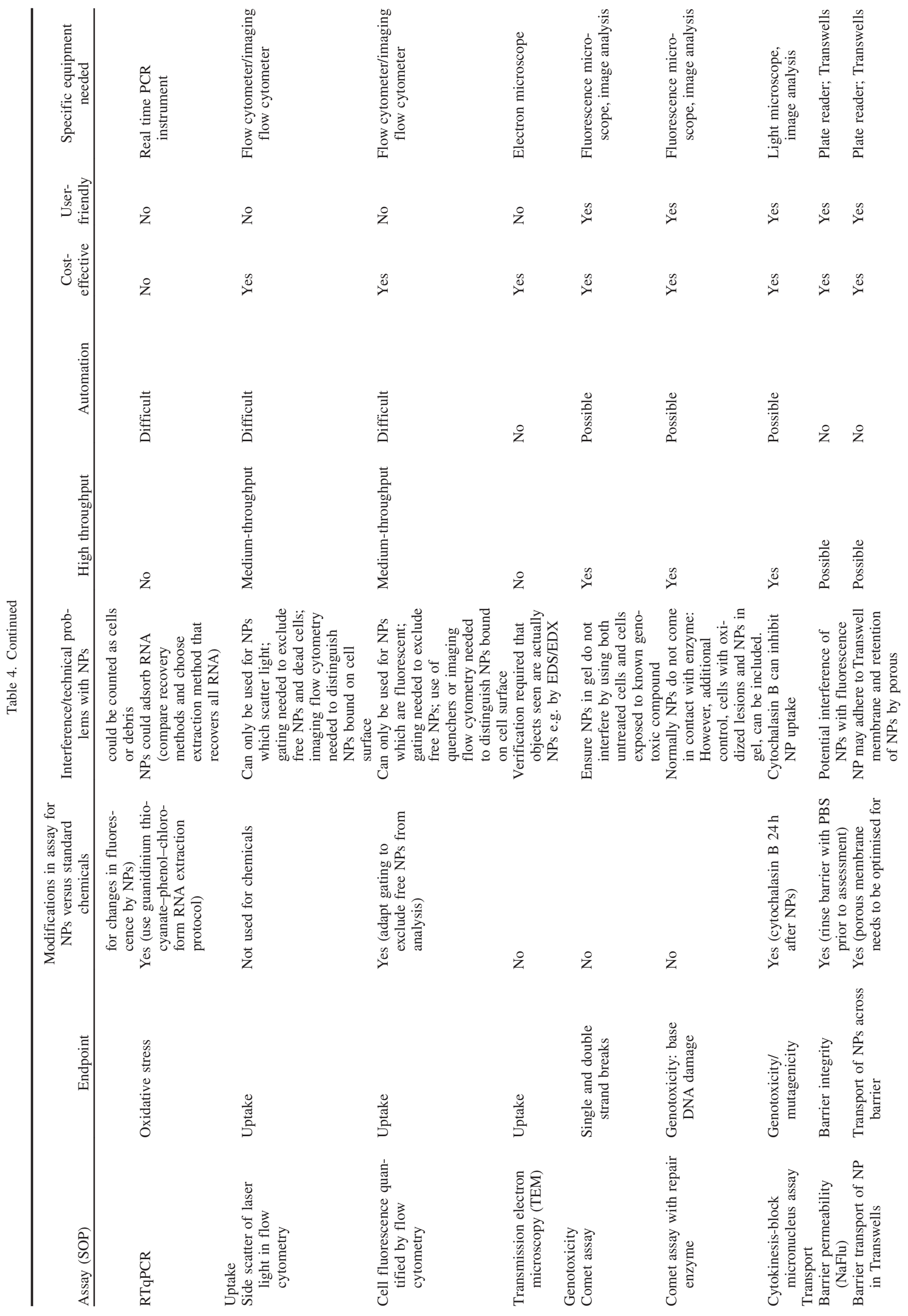




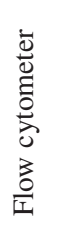

そ̊

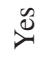

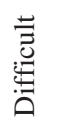

竞
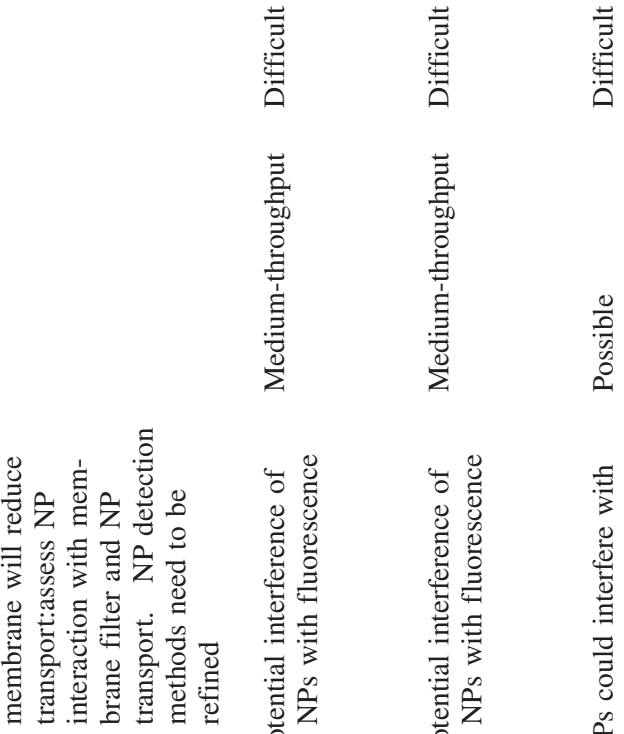

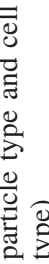

NPs using automated procedures on a predefined set of representative cells. Appropriate statistical analyses must always be implemented.

For the evaluation of the different cell models, depending on route of exposure and use of NPs there should be several organ models used for testing. Blood is an important model both as a direct target as well as surrogate target tissue and gives an indication of toxicity. Peripheral blood lymphocytes are suitable cells but unfortunately not always accessible; the TK6 (lymphoblastic) cell line is an alternative. We additionally propose that commercially available human cell lines for each representative organ be included in the testing strategy, e.g. for lung cells available cell lines (A549 cells is one alternative), $\mathrm{CaCo} 2$ cells (colon), LN229 cells (glioblastoma) and HEK293 or MDCK (human or porcine kidney, respectively).

For short-term hazard assessment, the testing strategy should include all important toxicity endpoints such as cytotoxicity, oxidative stress, genotoxicity or immunotoxicity to investigate the mode of action of NPs in biological systems. In vitro experiments with cells representing different organ targets revealed that oxidative stress and toxic effects induced by NPs depend on the NPs' properties, the test used and the cell type. Polylactic-coglycolic acid (PLGA-PEO) NPs induced little or no oxidative stress in any cell type compared with solid-core metallic NPs which generally produced ROS (Guadagnini et al., 2015b; Halamoda Kenzaoui et al., 2012c, 2013b). Genotoxicity induced by NPs depends on the NPs, the dispersion protocol and the measured endpoint (Magdolenova et al., 2012a). All cells tested were able to detect the positive response but with different sensitivity showing tissue specific effects (Cowie et al., 2015).

In the initial stages of testing, cytotoxicity assays should be used to identify non-cytotoxic concentrations of the NPs for more specific in vitro studies. Moreover, inclusion of nanospecific positive and negative controls is strongly recommended.

The strategy proposed for a battery of in vitro tests is explained as follows.

(1) To determine possible cytotoxicity and induction of oxidative stress.

- For cytotoxicity studies, basal cellular toxicity tests such as relative growth activity and plating efficiency and the MTT and WST- 1 assays and a time course of 24 and $72 \mathrm{~h}$, using OC- $\mathrm{Fe}_{3} \mathrm{O}_{4} \mathrm{NPs}$ as positive control NPs and PLGA-PEO NPs as negative control NPs.

- For oxidative stress, the thiol depletion measured by monobromobimane assay (and possibly DCFH-DA; Aranda et al., 2013) and the induction of antioxidant enzyme mRNA expression measured by RT-qPCR (Guadagini et al., 2015b), 4 and $24 \mathrm{~h}$ time-course, using uncoated iron oxide $\left(\mathrm{U}_{-} \mathrm{Fe}_{3} \mathrm{O}_{4}\right)$ NPs and $\mathrm{TiO}_{2}$ NPs as positive control NPs and PLGA-PEO NPs as negative control NPs.

(2) to determine the uptake and possible release, following uptake, of the NPs by relevant cells of the different organs, at non-cytotoxic concentrations of the NPs.

- For uptake, TEM and depending on NP properties flow cytometry (if light scattering or fluorescent) or analytical methods (ICP-MS). Analytical chemistry on cell supernatants could be used to study the release of NPs (dos Santos et al. 2011; Elsaesser et al, 2011).

- For uptake and release studies, $24 \mathrm{~h}$ uptake followed by $24 \mathrm{~h}$ release, using $\mathrm{U}-\mathrm{Fe}_{3} \mathrm{O}_{4}$ NPs as positive control NPs (Halamoda Kenzaoui et al., 2012b, 2013b).

- For transport studies, $24 \mathrm{~h}$ time-course, using $\mathrm{OC}-\mathrm{Fe}_{3} \mathrm{O}_{4}$ NPs as positive control NPs, limiting these experiments to NPs which do not agglomerate in the culture conditions (Correia Carreira et al., 2015; Halamoda Kenzaoui et al, 2013b). 


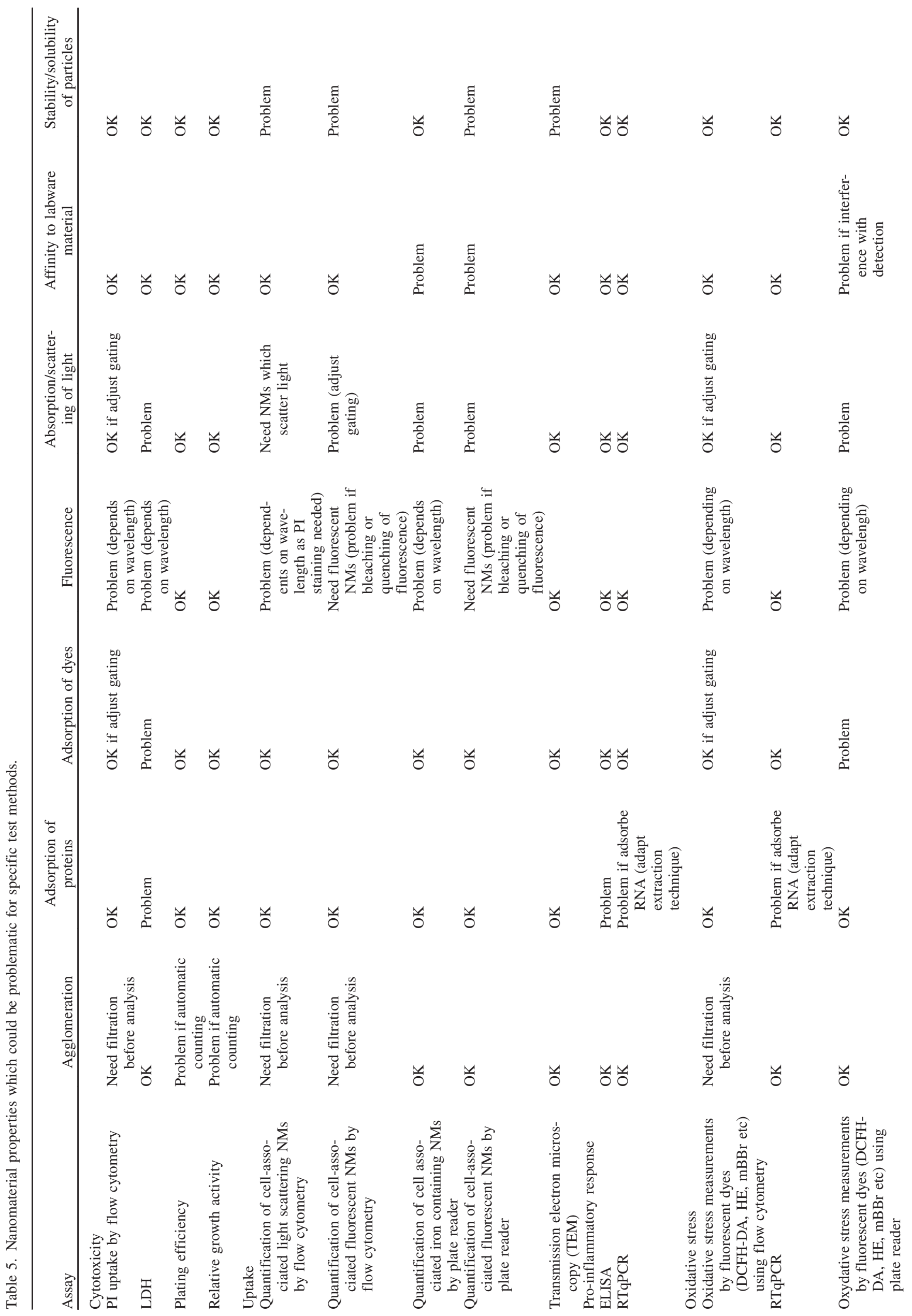




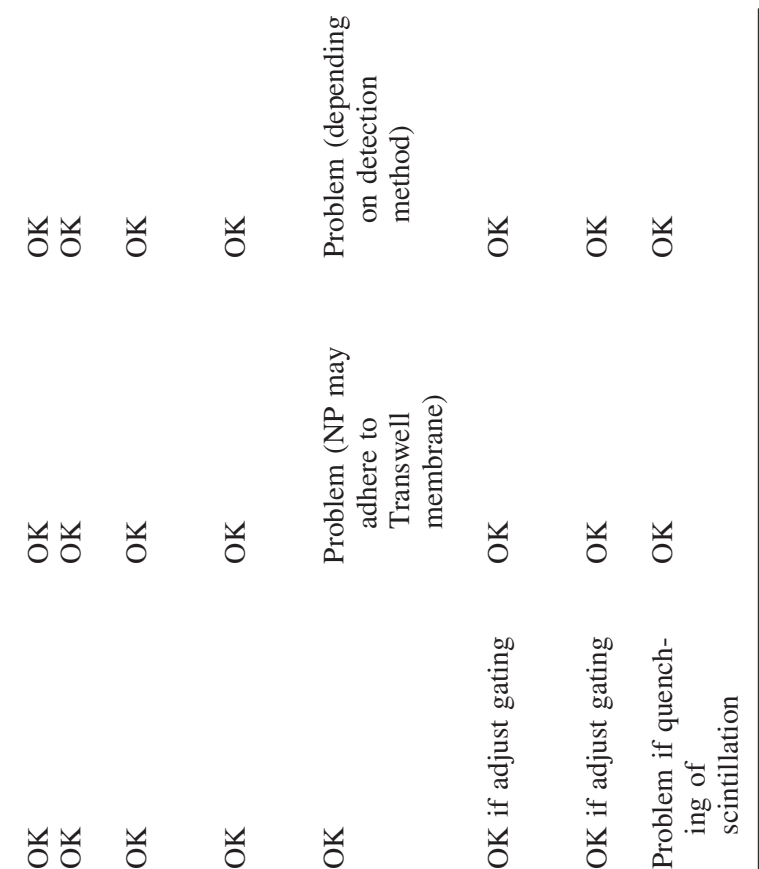

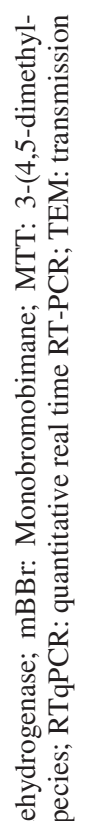

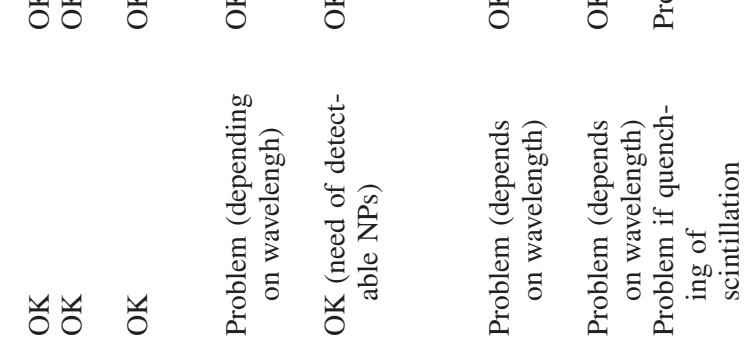

密

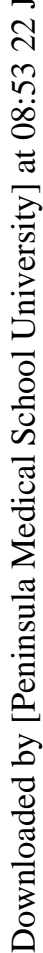

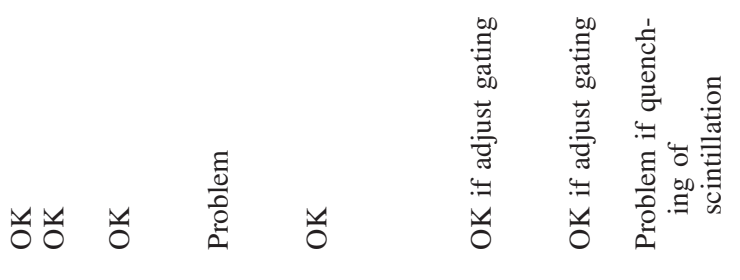

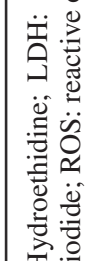

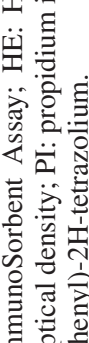

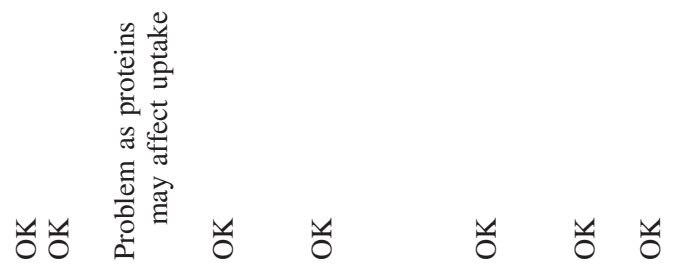

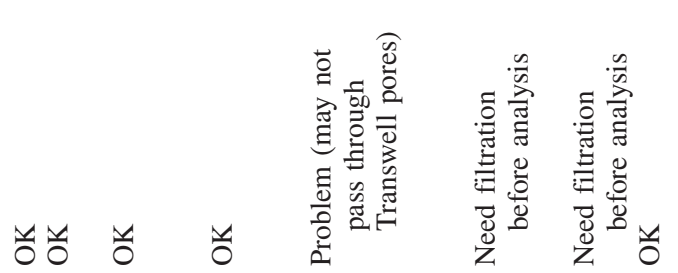

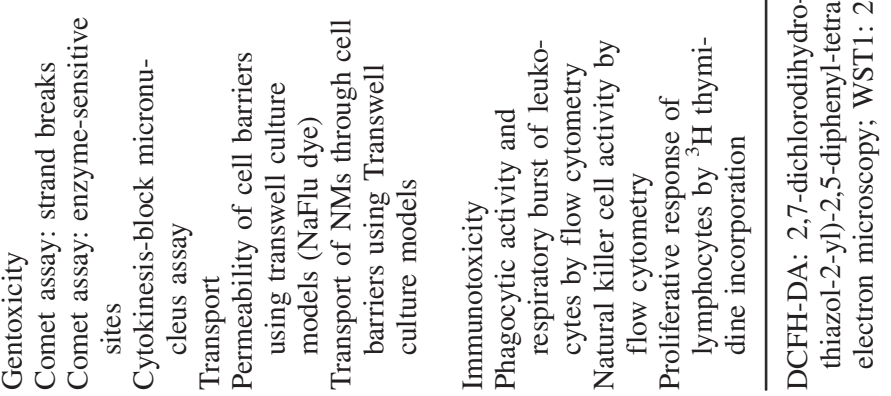


Table 6. General problems which may arise from specific nanomaterial properties and should be taken into consideration to choose the best testing strategy and for correct interpretation of results.

\begin{tabular}{|c|c|c|c|c|c|c|}
\hline Agglomeration & $\begin{array}{c}\text { Adsorption of } \\
\text { proteins }\end{array}$ & $\begin{array}{c}\text { Adsorption of } \\
\text { dyes/assay } \\
\text { reagents }\end{array}$ & Fluorescence & $\begin{array}{l}\text { Absorption/scat- } \\
\text { tering of light }\end{array}$ & $\begin{array}{l}\text { Affinity to lab- } \\
\text { ware material }\end{array}$ & $\begin{array}{c}\text { Stability/solubility } \\
\text { of particles }\end{array}$ \\
\hline $\begin{array}{l}\text { Problem for flow } \\
\text { cytometry }\end{array}$ & Change size & $\begin{array}{l}\text { Interference with } \\
\text { test methods }\end{array}$ & $\begin{array}{l}\text { Interference with } \\
\text { read-out system }\end{array}$ & $\begin{array}{l}\text { Interference with } \\
\text { read-out } \\
\text { system }\end{array}$ & $\begin{array}{l}\text { Interference with } \\
\text { read-out } \\
\text { system and } \\
\text { test methods }\end{array}$ & $\begin{array}{l}\text { Problem for dosage/ } \\
\text { detection }\end{array}$ \\
\hline Change settling & Change uptake & & $\begin{array}{l}\text { Change of surface } \\
\text { characteristics if } \\
\text { not core-labelled }\end{array}$ & & $\begin{array}{l}\text { Change } \\
\text { bioavailability }\end{array}$ & Change size \\
\hline $\begin{array}{l}\text { Pipetting (problem } \\
\text { for correct dosing } \\
\text { and } \\
\text { reproducibility) }\end{array}$ & $\begin{array}{l}\text { Change intracel- } \\
\text { lular transport }\end{array}$ & & $\begin{array}{l}\text { Problem of detection } \\
\text { if leaching or } \\
\text { bleaching }\end{array}$ & & $\begin{array}{l}\text { Problem for } \\
\text { dosage }\end{array}$ & Change uptake \\
\hline Change uptake & $\begin{array}{l}\text { Change } \\
\text { translocation }\end{array}$ & & $\begin{array}{l}\text { Problem if interfer- } \\
\text { ence with dyes }\end{array}$ & & & $\begin{array}{l}\text { Change intracellular } \\
\text { transport }\end{array}$ \\
\hline $\begin{array}{l}\text { Change intracellular } \\
\text { transport }\end{array}$ & $\begin{array}{l}\text { Change in } \\
\text { metabolism }\end{array}$ & & & & & \\
\hline
\end{tabular}

(3) to determine possible genotoxic effect (Magdolenova et al., 2012b,2014).

- For DNA damage, cells exposed for $24 \mathrm{~h}$ to NPs, using the comet assay for DNA strand breaks (SB) and oxidized DNA lesions $\left(\mathrm{TiO}_{2}\right.$ or $\mathrm{OC}-\mathrm{Fe}_{3} \mathrm{O}_{4}$ as positive control NPs and PLGA-PEO NPs as negative control NPs, at non-cytotoxic concentrations of NPs).

- For mutagenicity and clastogenicity, cytokinesis-block micronucleus (CBMN) modified protocol for NPs genotoxicity testing. However, positive and negative controls should be further specified.

- The $\gamma \mathrm{H} 2 \mathrm{AX}(\mathrm{H} 2 \mathrm{~A}$ histone family, member $\mathrm{X}$ ) assay is an interesting end-point for automated procedures, but little information so far exists about predicting NP-induced genotoxicity using this test.

- Gene mutation assays (in either tk or hprt locus) have not only been tested within NanoTEST, but should also be implemented into genotoxicity strategy to cover all genotoxicity endpoints.

(4) To determine immunosafety of NPs, human peripheral whole blood or isolated peripheral blood mononuclear cells (PBMC) as representatives of human blood cell model are proposed for in vitro screening of the immunotoxic potential of nanoproducts. The main strength is the complexity of the model containing several cell types and components in a relatively intact environment. Testing strategy for assessment of immunotoxic effect of NPs should contain a panel of immune assays to cover several aspects of the immune response. Cellular immune response: phagocytic activity and respiratory burst of leukocytes, natural killer cell activity, proliferative activity of lymphocytes in vitro stimulated with mitogens and/or antigens (LTT). Humoral immune response: production/expression of cytokines.

- For lymphocyte transformation test (LTT), fluorescent $25 \mathrm{~nm}$ silica (Fl-25 $\mathrm{SiO}_{2}$ ) NPs as immunosuppressive control and $\mathrm{TiO}_{2}$ NPs as possible candidate for immunostimulatory control.

- For phagocytic activity and respiratory burst assay, $\mathrm{U}-\mathrm{Fe}_{3} \mathrm{O}_{4}$ as stimulatory control and $\mathrm{OC}-\mathrm{Fe}_{3} \mathrm{O}_{4}$ as suppressive nanocontrol.

- For natural killer cell activity, $\mathrm{OC}-\mathrm{Fe}_{3} \mathrm{O}_{4} \mathrm{NPs}$ as suppressive control and Fl-25 $\mathrm{SiO}_{2} \mathrm{NPs}$ as stimulatory control.
- For cytokine gene expression, $\mathrm{OC}-\mathrm{Fe}_{3} \mathrm{O}_{4} \mathrm{NPs}$ as suppressive control for IL-6.

(5) Finally, to perform the more selective evaluations, as required by the particular characteristics of the organrepresentative cells, such as cytokine production, cellular localization of NPs inside cells using techniques such as confocal or electronic microscopy techniques, etc.

Tables 5 and 6 are intended to help choosing the best testing strategy (toxicity test/dispersion media/adaptation of standard methods) depending on the physico-chemical characteristics of the NPs.

Several assays appeared to be suitable for high throughput screening and automation (Table 4) and their implementation in a testing strategy is desirable for a large number of NPs. Increased throughput of the comet assay for detection of SBs and specific DNA lesions is suggested for robust testing together with automation and high throughput of assays for cytotoxicity (measuring cell count, nuclear intensity and nuclear size) and alternatively also for genotoxicity $(\gamma \mathrm{H} 2 \mathrm{AX}$ assay; Harris et al., 2015). It is recommended to use a multiparametric analysis (high content imaging - HCI) which provides more information and can allow determination of the cause of the cytotoxic effect. High-throughput screening (HTS) assays provide several benefits, including an upscaling of number of NPs to be tested; for optimization and precision of the assays; as a support to validations; and if applicable also for industrial use.

The quantitative structure-activity relationship [(Q)SAR] models promise to be valuable tools for future testing strategies. The theoretical model predicting oxidative stress potential led to the prioritisation of metal oxide NPs for further evaluation. The proposed model could be used to guide the development of more rational and efficient screening strategies; in addition, it can create a more coherent conceptual framework when additional toxicity related physicochemical properties (e.g. agglomeration and solubility in water) are included (Burelo \& Worth, 2011, 2015).

With proper refinement of computational models and methodologies, physiologically based pharmacokinetic (PBPK) modelling may serve as an alternative testing strategy in future (Pilou et al., 2015), replacing experiments that are expensive both in time and resources. 


\section{Conclusions and remarks}

A strategy for short-term hazard assessment and toxicity testing in a regulatory context requires a battery of tests addressing different mechanisms and covering all main important toxicity endpoints including oxidative stress, genotoxicity, inflammation and immunotoxicity. Toxicity tests should be performed in an appropriate treatment medium and uptake should be an integral part of the testing. Treatment should be long enough for the NPs to enter the cells and entry and uptake should be confirmed and quantified where possible (Elsaesser et al., 2011).

Appropriate controls and reference standards should be included in tests. The solvent and, if NPs are coated, the coating material need to be tested separately. Historical control data (for each cell type used) are valuable references for quality control. Toxicity tests must be accompanied by extensive characterization of NPs, including in test-media (before and after exposure), and covering primary and secondary properties of NPs. Number of cells, cell culture plate format and volume of treatment medium on the plate are important factors in expressing concentration and can impact on the effect of NPs, and so they should be constant within the study, especially when different NPs are compared. Concentration range and exposure time are also crucial aspects in toxicity testing and care must be taken to express concentrations in at least two different units, not only in mass but also in number of NPs or in surface area as this might be more representative for evaluation of toxicity of different NPs than using mass units. Determination of actual size and surface area is important as number or surface concentrations are sometimes based on the nominal particle size and may not reflect the actual particle size/ surface.

We propose that for full assessment of NP toxicity, at least 2-3 cytotoxicity tests (the MTT, WST-1 and plating efficiency assays or relative growth activity), a set of at least 2-3 representative cells and five NP concentrations should be used. Initially, the cytotoxicity response to the NPs must be determined, then oxidative stress response using at least two assays. A testing strategy for assessment of immunotoxic effects of NPs should contain assays covering several aspects of the immune response (inducible proliferative response, phagocytic activity and respiratory burst of leukocytes, natural killer cell activity, production/ expression of cytokines). For genotoxicity, the modified comet assay for DNA damage (strand breaks as well as oxidised DNA lesions) should be included in the testing strategy together with the micronucleus assay and a gene mutation test with the option of the $\gamma \mathrm{H} 2 \mathrm{AX}$ assay in automated procedures. The evaluation of internalization of NPs by cells should be an integral part of testing strategy but is not always feasible, and the analytical methods and the devices designed to evaluate NPs transport across cell layers need improvements in technology.

\section{Declaration of interest}

The authors declare that there is no conflict of interests. The work was supported by EC FP7 NanoTEST [Health-2007-1.3-4], Contract no: 201335, EC FP7 QualityNano [INFRA-2010-1.131], Contract no: 214547-2, EC FP7 NANoREG, [NMP.2012.1.3-3], Contract no: 310584, EC FP7 NanoTOES [PITN-GA-2010-264506] and by NILU internal projects 106179 . The work by UH Bristol was carried out with the support of the Bristol Centre for Nanoscience and Quantum Information, University of Bristol.

\section{References}

Aranda A, Sequedo L, Tolosa L, Quintas G, Burello E, Castell JV, Gombau L. 2013. Dichloro-dihydro-fluorescein diacetate (DCFH-DA) assay: a quantitative method for oxidative stress assessment of nanoparticle-treated cells. Toxicol in Vitro 27:954-63.
Bouwmeester H, Lynch I, Marvin HJP, Dawson KA, Berges M, Braguer D, et al. 2011. Minimal analytical characterization of engineered nanomaterials needed for hazard assessment in biological matrices. Nanotoxicology 5:1-11.

Burello E, Worth A. 2011. A theoretical framework for predicting the oxidative stress potential of oxide nanoparticles. Nanotoxicology 5: 228-35.

Burello E, Worth A. 2015. A rule for designing safer nanomaterials: do not interfere with the cellular redox equilibrium. Nanotoxicology 9(S1):116-117.

Cartwright L, Poulsen MS, Nielsen HM, Pojana G, Knudsen LE, Saunders M, Rytting E. 2011. In vitro placental model optimization for nanoparticle transport studies. Int J Nanomed 7:497-510.

Correia Carreira S, Walker L, Paul K, Saunders M. 2015. The toxicity, transport and uptake of nanoparticles in the in vitro BeWo b30 placental cell barrier model used within NanoTEST. Nanotoxicology 9(S1):66-78.

Cowie H, Magdolenova Z, Saunders M, Drlickova M, Correia Carreira S, Halamoda Kenzaoiu B, et al. 2015. Suitability of human and mammalian cells of different origin for the assessment of genotoxicity of metal and polymeric engineered nanoparticles. Nanotoxicology 9(S1):57-65.

dos Santos T, Varela J, Lynch I, Salvati A, Dawson KA. 2011. Quantitative assessment of the comparative nanoparticle-uptake efficiency of arrange of cell lines. Small 7:3341-9.

Dusinska M, Fjellsbø LM, Magdolenova Z, Ravnum S, Rinna A, RundenPran E. 2011. Chapter 11. Safety of nanomaterial in nanomedicine. In: Hunter RJ, Preedy VR, eds. Nanomedicine in Health and Disease. New Hampshire: Science Publishers [CRC Press], 203-26.

Dusinska M, Magdolenova Z, Fjellsbø LM. 2013. Toxicological aspects for nanomaterial in humans. Chapter 1. In: Oupicky D, Ogris M, eds. Nanotechnology for Nucleic Acid Delivery, Methods in Molecular Biology. New York: Humana Press, Springer BWF Book 948, 1-12.

Dusinska M, NanoTEST consortium. 2009. Safety of nanoparticles used in medical application. Development of alternative testing strategies for toxicity testing. Sci Technol Public Serv Rev 4:126-7.

Dusinska M, Rundén-Pran E, Carreira SC, Saunders M. 2012. In vitro and in vivo toxicity test methods. Chapter 4. Critical Evaluation of Toxicity Tests. In: Fadeel B, Pietroiusti A, Shvedova A, eds. Adverse Effects of Engineered Nanomaterials: Exposure, Toxicology and Impact on Human Health. New York: Elsevier, 63-84.

Elsaesser A, Barnes CA, McKerr G, Salvati A, Lynch I, Dawson KA, Howard CV. 2011. Quantification of nanoparticle uptake by cells using an unbiased sampling method and electron microscopy. Nanomedicine (Lond) 6(7):1189-98.

Elsaesser A, Howard CV. 2012. Toxicology of nanoparticles. Adv Drug Deliv Rev 64:129-37.

Gonzalez L, Corradi S, Thomassen LC, Martens JA, Cundari E, Lison D, Kirsch-Volders M. 2011. Methodological approaches influencing cellular uptake and cyto-(geno) toxic effects of nanoparticles. J Biomed Nanotechnol 7:3-5.

Guadagnini R, Halamoda Kenzaoui B, Cartwright L, Pojana G, Magdolenova Z, Bilanicova D, et al. 2015a. Toxicity screenings of nanomaterials: challenges due to interference with assay processes and components of classic in vitro tests. Nanotoxicology 9(S1):13-24.

Guadagnini R, Moreau K, Hussain S, Marano F, Boland S. 2015b. Toxicity evaluation of engineered nanoparticles for medical applications for the pulmonary system. Nanotoxicology 9(S1):25-32.

Hagens WI, Oomen AG, de Jong WH, Cassee FR, Sips AJ. 2007. What do we (need to) know about the kinetic properties of nanoparticles in the body? Regul Toxicol Pharmacol 49:217-29.

Halamoda Kenzaoui B, Angeloni S, Overstolz T, Niedermann P, ChapuisBernasconi C, Liley M, Juillerat-Jeanneret L. 2013a. Transfer of ultra small iron oxide nanoparticles from human brain-derived endothelial cells to human glioblastoma cells. ACS Appl Mater Interfaces 5:3581-6.

Halamoda Kenzaoui B, Bernasconi C, Hofmann H, Juillerat-Jeanneret L. 2012a. Evaluation of uptake and transport of ultra small super paramagnetic iron oxide nanoparticles by human brain-derived endothelial cells. Nanomedicine 7:39-53.

Halamoda Kenzaoui B, Chapuis Bernasconi C, Guney-Ayra S, JuilleratJeanneret L. 2012c. Induction of oxidative stress, lysosome activation and autophagy by nanoparticles in human brain endothelial cells. Biochem J 441:813-21. 
Halamoda Kenzaoui B, Chapuis Bernasconi C, Juillerat-Jeanneret L. 2013b. Stress-reaction of kidney epithelial cells to inorganic solid-core nanoparticles. Cell Biol Toxicol 29:39-58.

Halamoda Kenzaoui B, Vila MR, Miquel JM, Cengelli F, JuilleratJeanneret L. 2012b. Evaluation of uptake and transport of cationic and anionic ultrasmall iron oxide nanoparticles by human colon cells. Int J Nanomed, 7:1275-86.

Handy RD, van den Brink N, Chappell M, Mühling M, Behra R, Dusinska M, et al. 2012. Practical considerations for conducting ecotoxicity test methods with manufactured nanomaterials: what have we learnt so far? Ecotoxicology 21:933-72.

Harris G, Palosaari T, Magdolenova Z, Mennecozzi M, Gineste JM, Saavedra L, et al. 2015. Iron oxide nanoparticle toxicity testing using high throughput analysis and high content imaging. Nanotoxicology 9(S1):87-94.

Hassellöv M, Kaegi R. 2009. Analysis and characterization of manufactured nanoparticles in aquatic environments. In: Lead JR, Smith E, eds. Environmental and Human Health Impacts of Nanotechnology. West Sussex, United Kingdom: Blackwell Publishing Ltd, 211-66.

Hussain S, Thomassen LCJ, Ferecatu I, Borot C, Andreau K, Martens JA, et al. 2010. Carbon black and titanium dioxide nanoparticles elicit distinct apoptotic pathways in bronchial epithelial cells. Part Fibre Toxicol 7:10.

Jiang J, Oberdörster G, Biswas P. 2009. Characterization of size, surface charge, and agglomeration state of nanoparticle dispersions for toxicological studies. J Nanopart Res 11:77-89.

Juillerat-Jeanneret L, Dusinska M, Fjellesbo LM, Collins AR, Handy R, Riediker M. 2015. Biological impact assessment of nanomaterial used in nanomedicine. Introduction to the NanoTEST project. Nanotoxicology 9(S1):5-12.

Juillerat-Jeanneret L, Aguzzi A, Wiestler OD, Darekar P, Janzer RC. 1992. Dexamethasone selectively regulates the activity of enzymatic markers of cerebral endothelial cell lines. In Vitro Cell Dev Biol 28A:537-43

Karlsson HL. 2010. The comet assay in nanotoxicology research. Anal Bioanal Chem 398:651-66.

Kato H, Suzuki M, Fujita K, Horie M, Endoh S, Yoshida Y, et al. 2009. Reliable size determination of nanoparticles using dynamic light scattering method for in vitro toxicology assessment. Toxicol in Vitro 23:927-34.

Kazimirova A, Magdolenova Z, Barancokova M, Staruchova M, Volkovova K, Dusinska M. 2012. Genotoxicity testing of PLGA-PEO nanoparticles in TK6 cells by the comet assay and the cytokinesisblock micronucleus assay. Mutat Res 748:42-7.

Kroll A, Pillukat MH, Hahn D, Schnekenburger J. 2012. Interference of engineered nanoparticles with in vitro toxicity assays. Arch Toxicol 86: $1123-36$

Laborda F, Jimenez-lamana J, Bolea E, Castillo JR. 2013. Critical considerations for the determination of nanoparticle number concentrations, size and number size distributions by single particle ICP-MS. J Anal Atomic Spectrom 28:1220-32.

Lundqvist M, Stigler J, Cedervall T, Berggård T, Flanagan MB, Lynch I, et al. 2011. The evolution of the protein corona around nanoparticles: a test study. ACS Nano 5:7503-9.

Magdolenova Z, Bilaničová D, Pojana G, Fjellsbø LM, Hudecova A, Hasplova K, et al. 2012a. Impact of agglomeration and different dispersions of titanium dioxide nanoparticles on the human related in vitro cytotoxicity and genotoxicity. J Environ Monit 14:455-64.

Magdolenova Z, Lorenzo Y, Collins A, Dusinska M. 2012b. Can standard genotoxicity tests be applied to nanoparticles? J Toxicol Environ Health A 75:800-6.

Magdolenova Z, Collins AR, Kumar A, Dhawan A, Stone V, Dusinska M. 2014. Mechanisms of genotoxicity. Review of recent in vitro and in vivo studies with engineered nanoparticles. Nanotoxicology 8:233-78.

Magdolenova Z, Drlickova M, Henjum K, Rundén-Pran E, Tulinska J, Bilanicova D, et al. 2015. Coating-dependent induction of cytotoxicity and genotoxicity of iron oxide nanoparticles. Nanotoxicology 9(S1):44-56

Mahon E, Salvati A, Baldelli Bombelli F, Lynch I, Dawson KA. 2012. Designing the nanoparticle-biomolecule interface for "targeting and therapeutic delivery". J Control Release 161:164-74.

Mortensen NP, Hurst GB, Wang W, Foster CM, Nallathamby PD, Retterer ST. 2013. Dynamic development of the protein corona on silica nanoparticles: composition and role in toxicity. Nanoscale 5:6372-80.
Oberdörster G, Maynard A, Donaldson K, Castranova V, Fitzpatrick J, Ausman K, et al. 2005. Principles for characterizing the potential human health effects from exposure to nanomaterials: elements of a screening strategy. Part FibreToxicol 2:8.

OECD. 2012. Environment, health and safety publications series on the safety of manufactured nanomaterials No. 36. Guidance on sample preparation and dosimetry for the safety testing of manufactured nanomaterials. ENV/JM/MONO(2012) 40:1-93.

Pilou M, Mavrofrydi O, Housiadas C, Eleftheriadis K, Papazafiri P. 2015. Computational modeling as part of an alternative testing strategies in the respiratory and cardiovascular systems: inhaled nanoparticle dose modeling based on representative aerosol measurements and corresponding toxicological analysis. Nanotoxicology 9(S1):106-115.

Poulsen MS, Mose T, Maroun LL, Mathiesen L, Knudsen LE, Rytting E. 2015. Kinetics of silica nanoparticles in the human placenta Nanotoxicology 9(S1):79-86.

Powers KW, Palazuelos M, Moudgil BM, Roberts SM. 2007. Characterization of the size, shape, and state of dispersion of nanoparticles for toxicological studies. Nanotoxicology 1:42-51.

Ragnaill MN, Brown M, Ye D, Bramini M, Callanan S, Lynch I, Dawson KA. 2011. Internal bench-marking of a human blood-brain barrier cell modelling for screening of nanoparticle uptake and transcytosis. Eur J Pharm Biopharm 77:360-7.

Ramirez-Garcia S, Chen L, Morris MA, Dawson KA. 2011. A new methodology for studying nanoparticle interactions in biological systems: dispersing titania in biocompatible media using chemical stabilisers. Nanoscale 3:4617-24.

Saunders M. 2009. Transplacental transport of nanomaterials. Wiley Interdiscip Rev Nanomed Nanobiotechnol 1:671-84.

Schütz CA, Staedler D, Crosbie-Staunton K, Movia D, Chapuis Bernasconi C, Halamoda Kenzaoui B, et al. 2014. Differential stress reaction of human colon cells to oleic acid-stabilized and unstabilized ultra small iron oxide nanoparticles. Int J Nanomed 9:3481-98.

Sebekova K, Dusinska M, Simon Klenovics K, Kollarova R, Boor P, et al. 2014. Comprehensive assessment of nephrotoxicity of intravenously administered sodium-oleate-coated ultra small super paramagnetic iron oxide (USPIO) and titanium dioxide (TiO2) nanoparticles in rats. Nanotoxicology 8:142-57.

Stefaniak AB, Hackley VA, Roebben G, Ehara K, Hankin S, Postek MT, et al. 2013. Nanoscale reference materials for environmental, health and safety measurements: needs, gaps and opportunities. Nanotoxicology 7:1325-37.

Stone V, Johnston H, Schins RPF. 2009. Development of in vitro systems for nanotoxicology: methodological considerations. Crit Rev Toxicol 39:613-26.

Stone V, Nowack B, Baun A, van den Brink N, von der Kammer F, Dusinska M, et al. 2010. Nanomaterials for environmental studies: classification, reference material issues, and strategies for physicochemical characterization. Sci Total Environ 408:1745-54.

Taurozzi JS, Hackley AH, Wiesner MR. 2011. Ultrasonic dispersion of nanoparticles for environmental, health and safety assessment - issues and recommendations. Nanotoxicology 5:711-29.

Tulinska J, Kazimirova A, Kuricova M, Barancokova M, Liskova A, Neubauerova E, et al. 2015. Immunotoxicity and genotoxicity testing of PLGA-PEO nanoparticles in human blood cell model. Nanotoxicology 9(S1):33-43.

Volkovova K, Handy R, Ulicna O, Kucharska J, Staruchova M, Kebis A, et al. 2015. Health effects of selected nanoparticles in vivo: Liver function and hepatotoxicity following intravenous injection of titanium dioxide and Na-oleate coated iron oxide nanoparticles in rodents. Nanotoxicology 9(S1):95-105.

Warheit DB. 2008. How meaningful are the results of nanotoxicity studies in the absence of adequate material characterization? Toxicol Sci 101: $183-5$.

Wittmaack K. 2011. Excessive delivery of nanostructured matter to submersed cells caused by rapid gravitational settling. ACS Nano 5: 3766-78.

Yang ST, Liu Y, Wang YW, Cao A. 2013. Biosafety and bioapplication of nanomaterials by designing protein-nanoparticle interactions. Small 9: $1635-53$.

Zuin S, Pojana, G, Marcomini, A. 2007. Effect-oriented physicochemical characterization of nanomaterials. In: Monteiro-Riviere NA, Tran CL, eds. Nanotoxicology: Characterization, Dosing and Health Effects. 1st ed. New York: Informa Healthcare, 19-57. 